\title{
LEVEL II SCOUR ANALYSIS FOR BRIDGE 20 (MENDTH00070020) on TOWN HIGHWAY 7, crossing MENDON BROOK, MENDON, VERMONT
}

Open-File Report 98-527

Prepared in cooperation with

VERMONT AGENCY OF TRANSPORTATION

and

FEDERAL HIGHWAY ADMINISTRATION

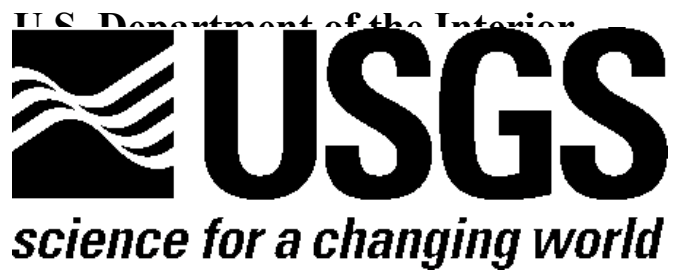


LEVEL II SCOUR ANALYSIS FOR BRIDGE 20 (MENDTH00070020) on TOWN HIGHWAY 7, crossing MENDON BROOK, MENDON, VERMONT

By SUSAN A. WILLOUGHBY and TIMOTHY SEVERANCE

U.S. Geological Survey

Open-File Report 98-527

Prepared in cooperation with

VERMONT AGENCY OF TRANSPORTATION and

FEDERAL HIGHWAY ADMINISTRATION 


\title{
U.S. DEPARTMENT OF THE INTERIOR BRUCE BABBITT, Secretary
}

\author{
U.S. GEOLOGICAL SURVEY
}

Thomas J. Casadevall, Acting Director

For additional information write to:

District Chief

U.S. Geological Survey 361 Commerce Way

Pembroke, NH 03275-3718
Copies of this report may be purchased from:

U.S. Geological Survey

Branch of Information Services

Open-File Reports Unit

Box 25286

Denver, CO 80225-0286 


\section{CONTENTS}

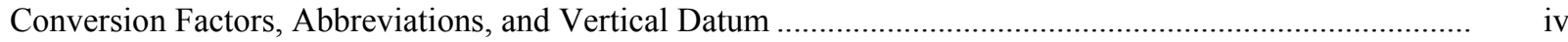

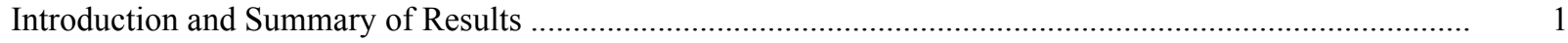

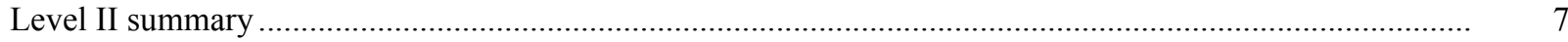

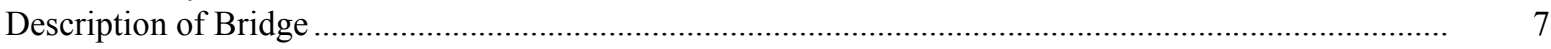

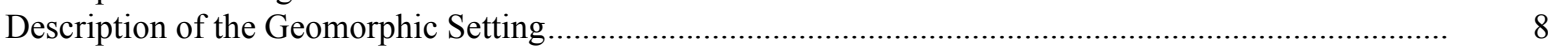

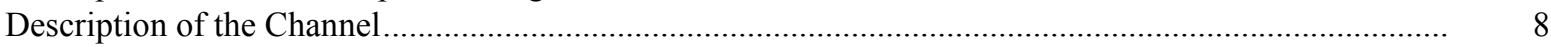

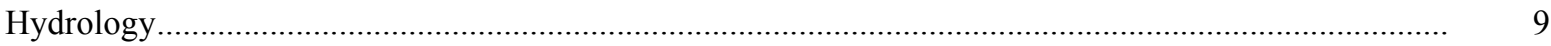

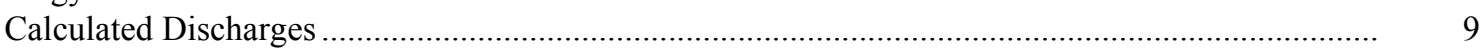

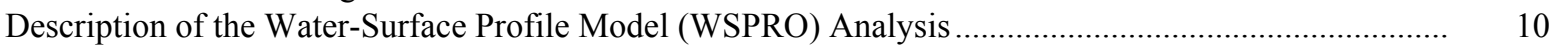

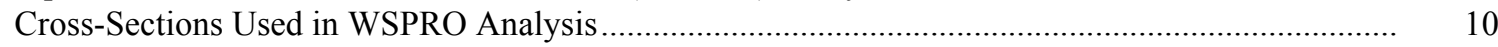

Data and Assumptions Used in WSPRO Model ........................................................................ 11

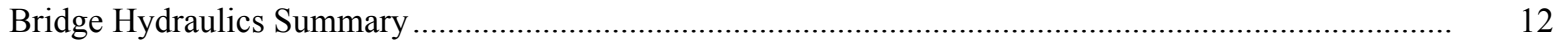

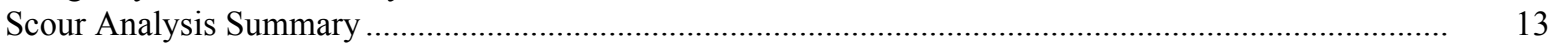

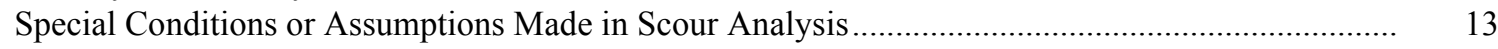

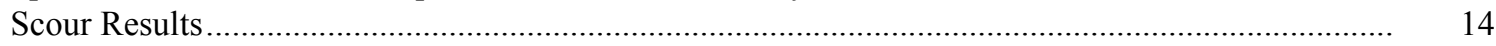

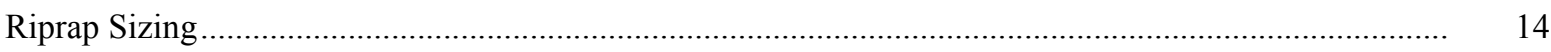

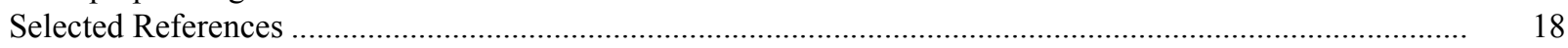

Appendices:

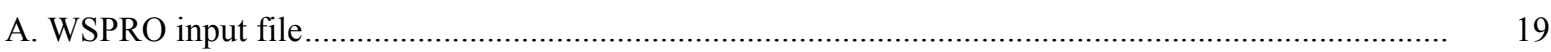

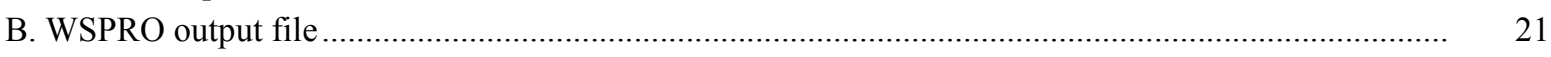

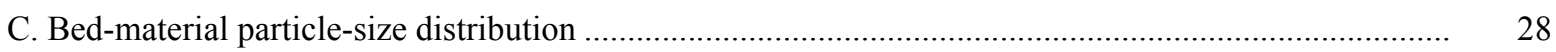

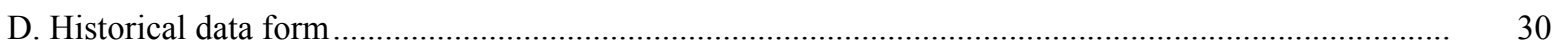

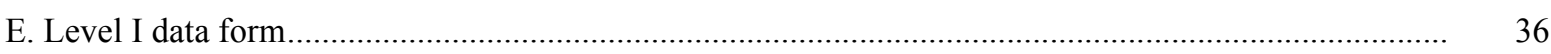

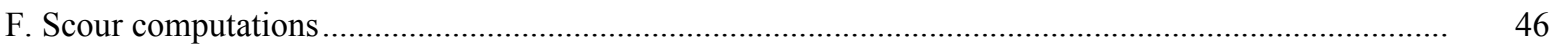

\section{FIGURES}

1. Map showing location of study area on USGS 1:24,000 scale map

2. Map showing location of study area on Vermont Agency of Transportation town highway map

3. Structure MENDTH00070020 viewed from upstream (September 27, 1995)

4. Downstream channel viewed from structure MENDTH00070020 (September 27, 1995)

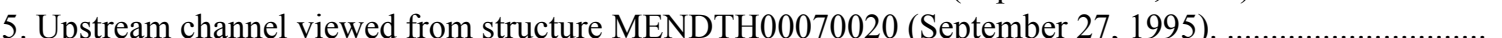

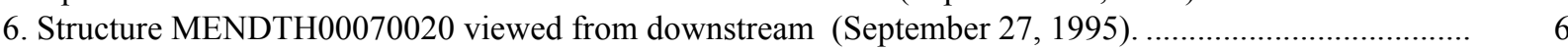

7. Water-surface profiles for the 100- and 500-year discharges at structure

MENDTH00070020 on Town Highway 7, crossing Mendon Brook, Mendon Vermont.............. 15

8. Scour elevations for the 100- and 500-year discharges at structure

MENDTH00070020 on Town Highway 7, crossing Mendon Brook, Mendon, Vermont............. 16

\section{TABLES}

1. Remaining footing/pile depth at abutments for the 100-year discharge at structure

MENDTH00070020 on Town Highway 7, crossing Mendon Brook, Mendon, Vermont .................

2. Remaining footing/pile depth at abutments for the 500-year discharge at structure

MENDTH00070020 on Town Highway 7, crossing Mendon Brook, Mendon, Vermont 


\begin{tabular}{|c|c|c|}
\hline Multiply & By & To obtain \\
\hline \multicolumn{3}{|c|}{ Length } \\
\hline inch (in.) & 25.4 & millimeter (mm) \\
\hline foot $(\mathrm{ft})$ & 0.3048 & meter $(\mathrm{m})$ \\
\hline mile (mi) & 1.609 & kilometer (km) \\
\hline \multicolumn{3}{|c|}{ Slope } \\
\hline foot per mile ( $\mathrm{ft} / \mathrm{mi})$ & 0.1894 & meter per kilometer $(\mathrm{m} / \mathrm{km})$ \\
\hline \multicolumn{3}{|c|}{ Area } \\
\hline square mile $\left(\mathrm{mi}^{2}\right)$ & 2.590 & square kilometer $\left(\mathrm{km}^{2}\right)$ \\
\hline \multicolumn{3}{|c|}{ Volume } \\
\hline cubic foot $\left(\mathrm{ft}^{3}\right)$ & $\begin{array}{l}0.02832 \\
\text { Velocity and Flow }\end{array}$ & cubic meter $\left(\mathrm{m}^{3}\right)$ \\
\hline foot per second (ft/s) & 0.3048 & meter per second $(\mathrm{m} / \mathrm{s})$ \\
\hline cubic foot per second $\left(\mathrm{ft}^{3} / \mathrm{s}\right)$ & 0.02832 & cubic meter per second $\left(\mathrm{m}^{3} / \mathrm{s}\right)$ \\
\hline $\begin{array}{l}\text { cubic foot per second per } \\
\text { square mile } \\
{\left[\left(\mathrm{ft}^{3} / \mathrm{s}\right) / \mathrm{mi}^{2}\right]}\end{array}$ & 0.01093 & $\begin{array}{l}\text { cubic meter per } \\
\text { second per square } \\
\text { kilometer }\left[\left(\mathrm{m}^{3} / \mathrm{s}\right) / \mathrm{km}^{2}\right]\end{array}$ \\
\hline
\end{tabular}

\section{OTHER ABBREVIATIONS}

\begin{tabular}{|c|c|c|c|}
\hline $\mathrm{BF}$ & bank full & LWW & left wingwall \\
\hline $\mathrm{cfs}$ & cubic feet per second & Max & maximum \\
\hline $\mathrm{D}_{50}$ & median diameter of bed material & $\mathrm{MC}$ & main channel \\
\hline DS & downstream & $\mathrm{RAB}$ & right abutment \\
\hline elev. & elevation & RABUT & face of right abutment \\
\hline $\mathrm{f} / \mathrm{p}$ & flood plain & $\mathrm{RB}$ & right bank \\
\hline $\mathrm{ft}^{2}$ & square feet & $\mathrm{ROB}$ & right overbank \\
\hline $\mathrm{ft} / \mathrm{ft}$ & feet per foot & RWW & right wingwall \\
\hline FEMA & Federal Emergency Management Agency & $\mathrm{TH}$ & town highway \\
\hline FHWA & Federal Highway Administration & UB & under bridge \\
\hline JCT & junction & US & upstream \\
\hline LAB & left abutment & USGS & United States Geological Survey \\
\hline LABUT & face of left abutment & VTAOT & Vermont Agency of Transportation \\
\hline LB & left bank & WSPRO & water-surface profile model \\
\hline LOB & left overbank & $\mathrm{yr}$ & year \\
\hline
\end{tabular}

In this report, the words "right" and "left" refer to directions that would be reported by an observer facing downstream.

Sea level: In this report, "sea level" refers to the National Geodetic Vertical Datum of 1929-- a geodetic datum derived from a general adjustment of the first-order level nets of the United States and Canada, formerly called Sea Level Datum of 1929.

In the appendices, the above abbreviations may be combined. For example, USLB would represent upstream left bank. 


\title{
LEVEL II SCOUR ANALYSIS FOR BRIDGE 20 (MENDTH00070020) ON TOWN HIGHWAY 7, CROSSING MENDON BROOK, MENDON, VERMONT
}

\author{
By Susan A. Willoughby and Timothy Severance
}

\section{INTRODUCTION AND SUMMARY OF RESULTS}

This report provides the results of a detailed Level II analysis of scour potential at structure MENDTH00070020 on Town Highway 7 crossing Mendon Brook, Mendon, Vermont (figures 1-8). A Level II study is a basic engineering analysis of the site, including a quantitative analysis of stream stability and scour (Federal Highway Administration, 1993). Results of a Level I scour investigation also are included in appendix E of this report. A Level I investigation provides a qualitative geomorphic characterization of the study site. Information on the bridge, gleaned from Vermont Agency of Transportation (VTAOT) files, was compiled prior to conducting Level I and Level II analyses and is found in appendix D.

The site is in the Taconic section of the New England physiographic province in south central Vermont. The $11.9-\mathrm{mi}^{2}$ drainage area is in a predominantly rural and forested basin. In the vicinity of the study site, the surface cover is forested upstream and downstream of the bridge.

In the study area, Mendon Brook is sinuous with a slope of approximately $0.006 \mathrm{ft} / \mathrm{ft}$, an average channel top width of $57 \mathrm{ft}$ and an average bank height of $5 \mathrm{ft}$. The channel bed material ranges from gravel to boulders with a median grain size $\left(D_{50}\right)$ of $123.1 \mathrm{~mm}(0.404$ $\mathrm{ft}$ ). The geomorphic assessment at the time of the Level I and Level II site visit on September 27, 1995 indicated that the reach was laterally unstable. Multiple point bars and cut-banks with slip failure of the bank material were observed both upstream and downstream of the site.

The Town Highway 7 crossing of Mendon Brook is a 30-ft-long, one-lane bridge consisting of one 26-foot steel-beam span (Vermont Agency of Transportation, written communication, March 13, 1995). The opening length of the structure parallel to the bridge face is $23.9 \mathrm{ft}$. The bridge is supported by vertical, concrete abutments with wingwalls. The channel is skewed approximately 40 degrees to the opening while the computed openingskew-to-roadway is 25 degrees. 
As observed during the Level I assessment, the left and right abutments were undermined vertically by 0.5 and 1.0 foot, respectively. The downstream right wingwall also was undermined by 0.3 feet vertically. The only scour protection measure at the site was type- 2 stone fill (less than 36 inches diameter) at the upstream end of the upstream left wingwall. Additional details describing conditions at the site are included in the Level II Summary and appendices $\mathrm{D}$ and $\mathrm{E}$.

Scour depths and recommended rock rip-rap sizes were computed using the general guidelines described in Hydraulic Engineering Circular 18 (Richardson and Davis, 1995) for the 100- and 500-year discharges. In addition, the incipient roadway-overtopping discharge was determined and analyzed as another potential worst-case scour scenario. Total scour at a highway crossing is comprised of three components: 1) long-term streambed degradation; 2) contraction scour (due to accelerated flow caused by a reduction in flow area at a bridge) and; 3 ) local scour (caused by accelerated flow around piers and abutments). Total scour is the sum of the three components. Equations are available to compute depths for contraction and local scour and a summary of the results of these computations follows.

There was no computed contraction scour for the modelled discharges. Abutment scour ranged from 10.4 to $15.2 \mathrm{ft}$. The worst-case left abutment scour occurred at the 500-year discharge. Additional information on scour depths and depths to armoring are included in the section titled "Scour Results". Scoured-streambed elevations, based on the calculated scour depths, are presented in tables 1 and 2. A cross-section of the scour computed at the bridge is presented in figure 8 . Scour depths were calculated assuming an infinite depth of erosive material and a homogeneous particle-size distribution.

It is generally accepted that the Froehlich equation (abutment scour) gives "excessively conservative estimates of scour depths" (Richardson and Davis, 1995, p. 46). Usually, computed scour depths are evaluated in combination with other information including (but not limited to) historical performance during flood events, the geomorphic stability assessment, existing scour protection measures, and the results of the hydraulic analyses. Therefore, scour depths adopted by VTAOT may differ from the computed values documented herein. 


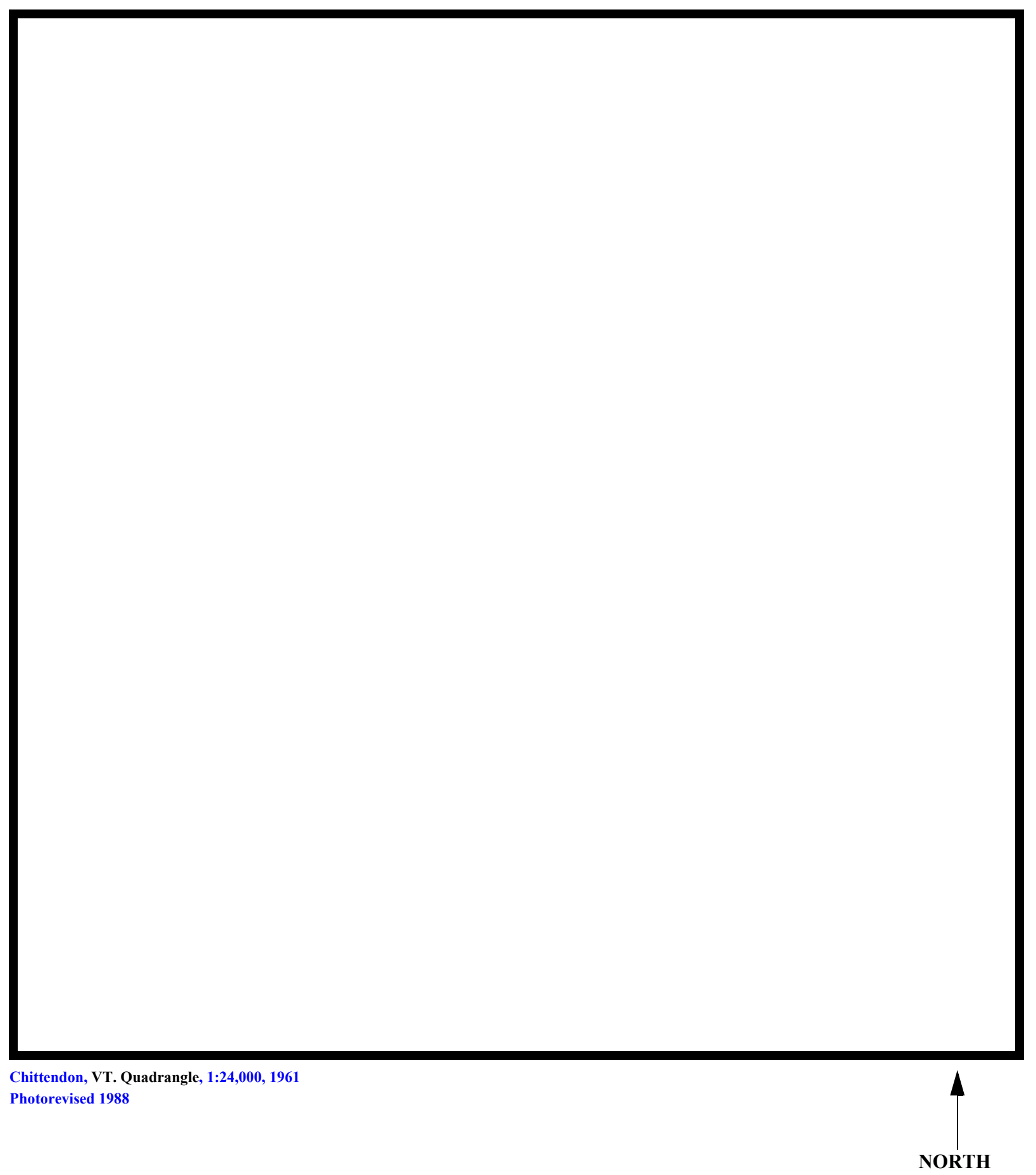

Figure 1. Location of study area on USGS 1:24,000 scale map. 
Figure 2. Location of study area on Vermont Agency of Transportation town highway map. 

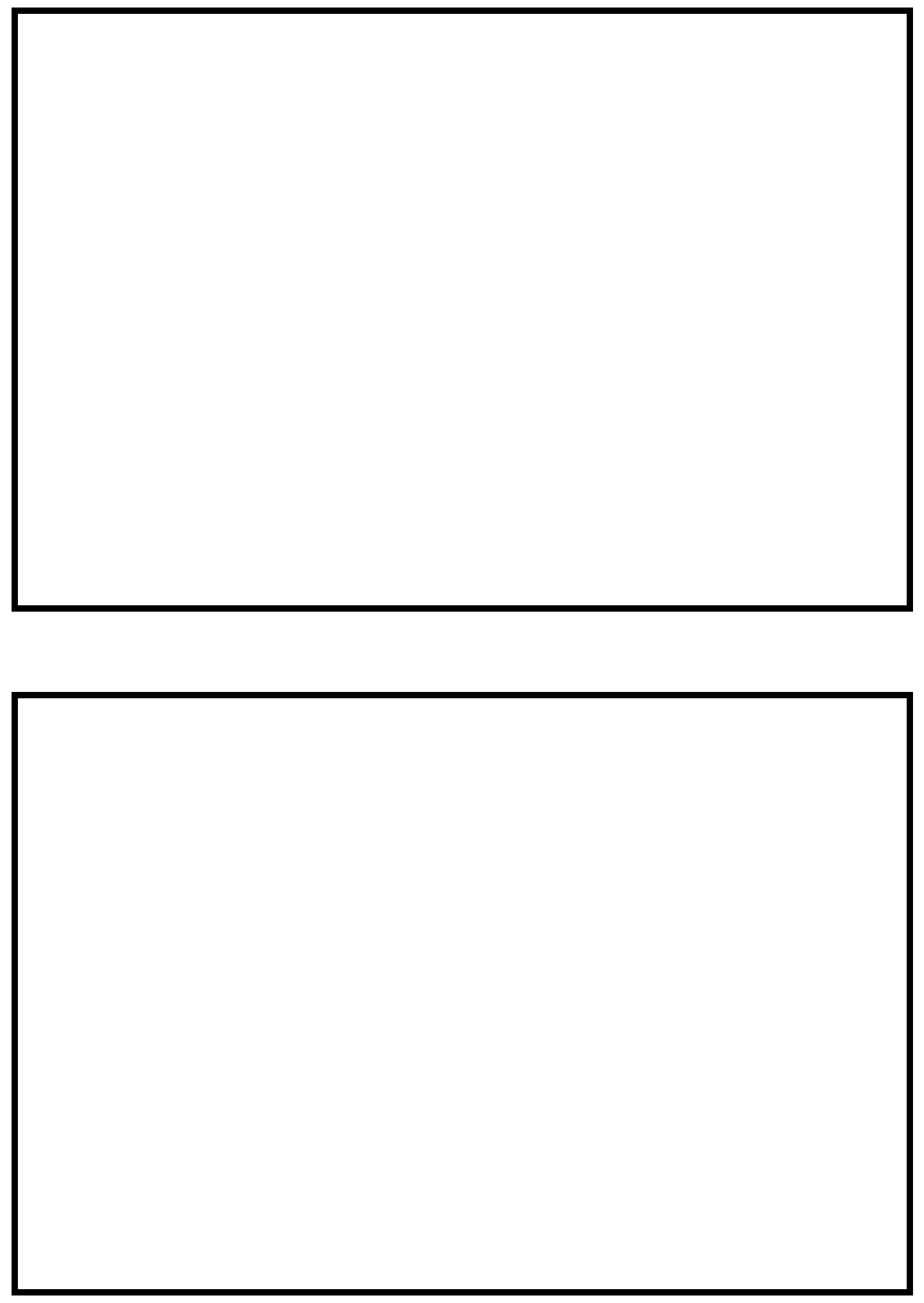

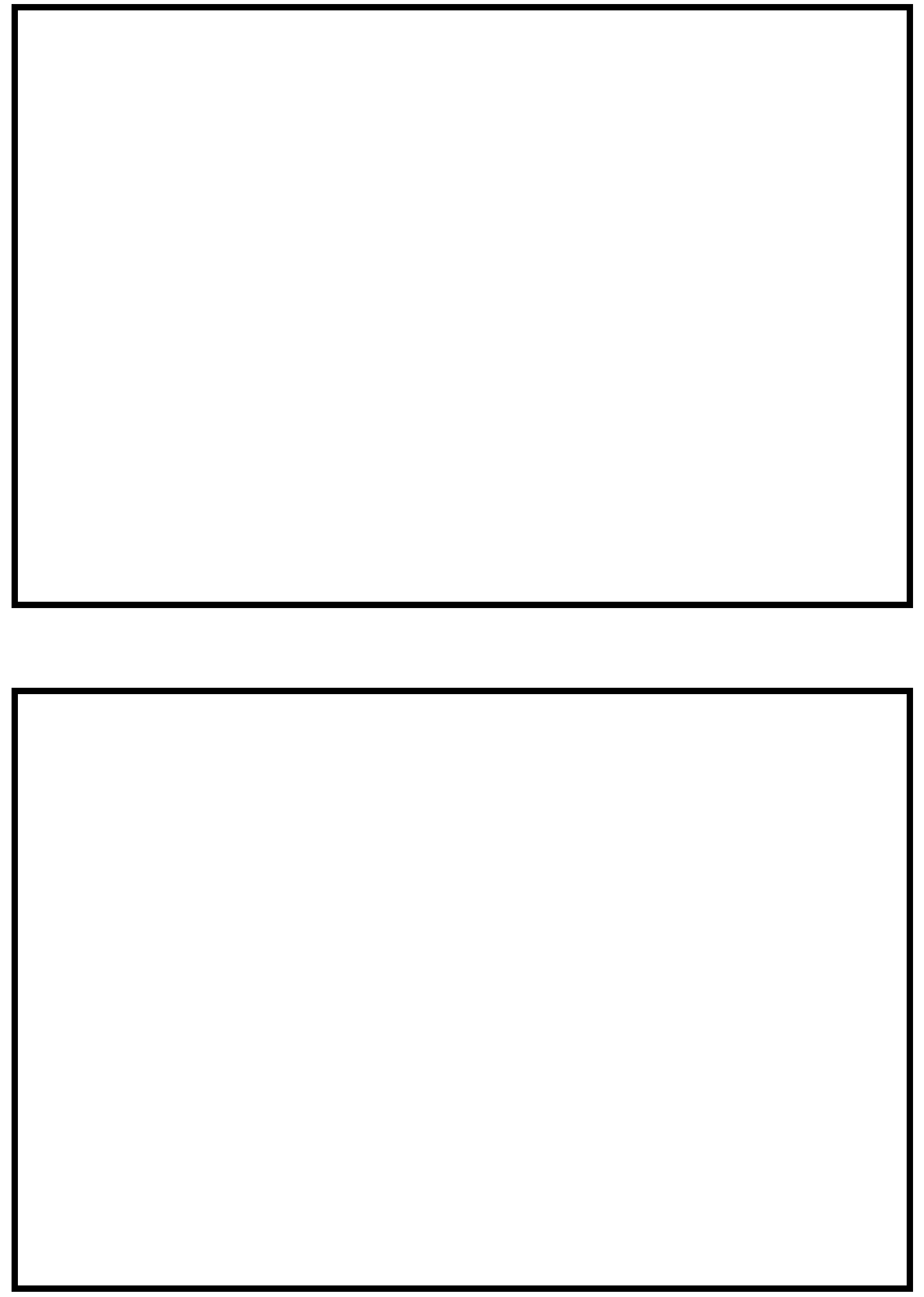


\section{LEVEL II SUMMARY}

\begin{tabular}{llllll} 
Structure Number & MENDTH00070020 & \multirow{2}{*}{ Stream } & \multicolumn{3}{c}{ Mendon Brook } \\
& Road & TH 7 & District & 3 \\
County & Rutland & & Roal
\end{tabular}

\section{Description of Bridge}

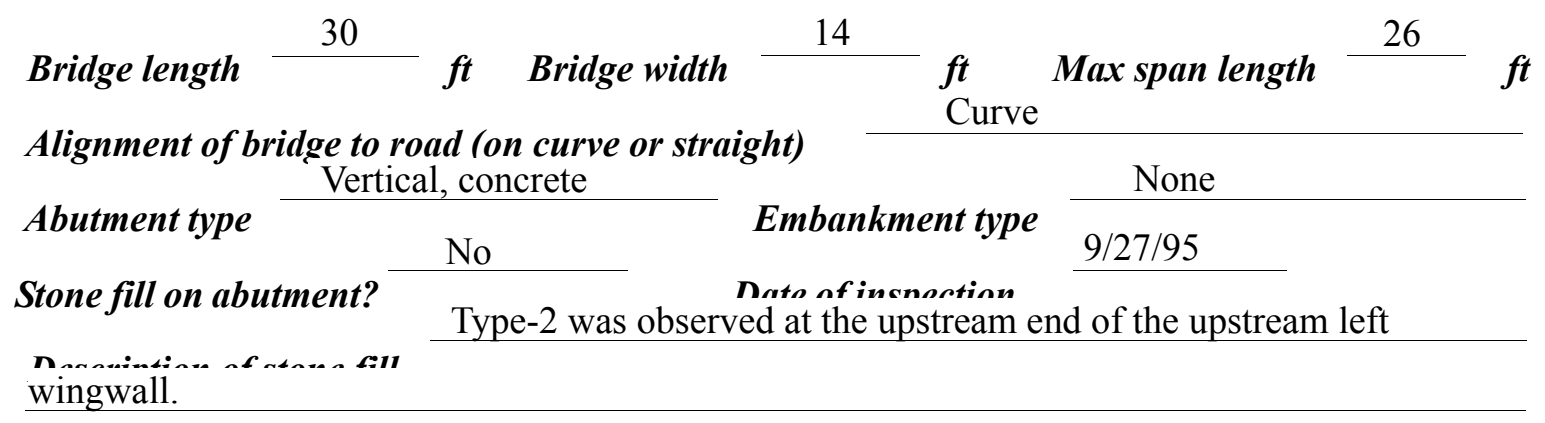

_ Abutments and wingwalls are concrete. There is a 1.25

$\mathrm{ft}$ deep scour hole upstream of the upstream right wingwall and along the left abutment. Both abutments and the downstream right wingwall are undermined.

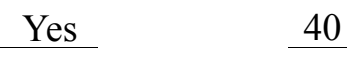

Is bridge skewed to flood flow according to Yes 'survey? Angle

There is a mild channel bend through the bridge. Scour holes have developed under the bridge in an area where the stream narrows in an upstream to downstream direction.

Debris accumulation on bridge at time of Level I or Level II site visit:

Date of insnortion
$9 / 27 / 95$

$9 / 27 / 95$

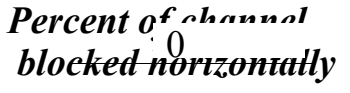

0
Percent of ${ }_{0}^{f}$......el
blocked verticatty

0
Level I

Level II trees falling into the channel.

Potential for debris

On 9/27/95, there were point bars observed on the right and left banks upstream, and large piles Doscriho anv foaturos noar ar at tho hridoo that mav, affoct flow, (includo ahsorvation dato) of boulders on the left and right banks near the upstream bridge face, which set up eddy currents through the bridge. 


\section{Description of the Geomorphic Setting}

General topography The channel is located in a moderate relief valley setting with little or no flood plain and steep valley walls.

Geomorphic conditions at bridge site: downstream (DS), upstream (US)

Date of inspection $\quad 9 / 27 / 95$

DS left: $\quad$ Steep channel bank and a narrow overbank.

DS right: Steep channel bank and a moderately sloped overbank.

US left: $\quad$ Steep channel bank and a moderately sloped overbank.

US right: $\quad$ Steep channel bank and a moderately sloped overbank.

\section{Description of the Channel}

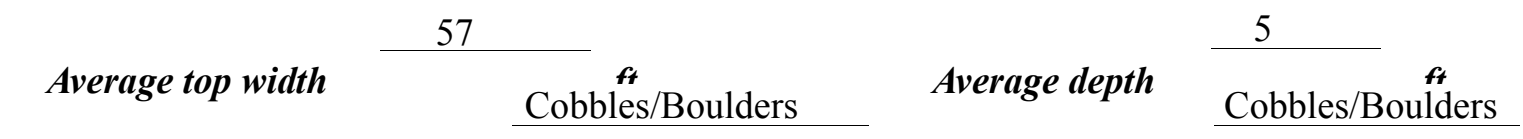

Predominant bed material

Bank material Perennial, and

sinuous but stable, with non-alluvial channel boundaries.

$9 / 27 / 95$

Vegetative co 1 Trees

DS left: $\quad$ Trees

DS right: Trees

US left: $\quad$ Trees

US right: $\quad$ No

Do banks appear stable? Several cut-banks and point bars were observed on 9/27/95 along the reach. Slip-failure of bank material and tree root exposure was observed at the cut-banks.
date of observatton.

None were observed

on $9 / 27 / 95$

Describe any obstructions in channel and date of observation. 


\title{
Hydrology
}

Drainage area $\frac{11.9}{m_{i}{ }^{2}}$

Percentage of drainage area in physiographic provinces: (approximate)

Physiographic province/section New England/Taconic
Percent of drainage area 100

\begin{abstract}
Is drainage area considered rural or urban?
Rural None.

urbanization:

Describe any significant
\end{abstract}

Is there a USGS gage on the stream of interest?

No

USGS gage description

USGS gage number

Gage drainage area $\mathrm{mi}^{2}$ $--$

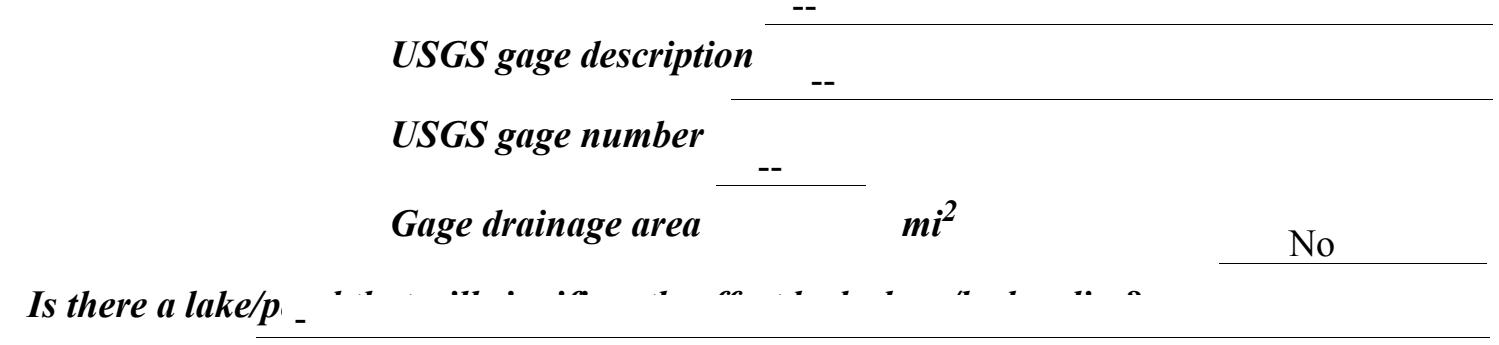

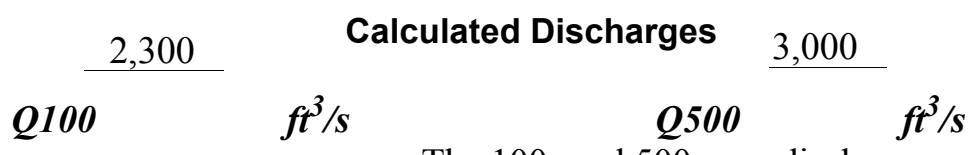

The 100- and 500-year discharges selected were

based on flood frequency estimates agailable in the VTAOT database (written communication, May 1995). These selected discharges were within the range defined by flood frequency curves derived from various empirical methods (Johnson and Tasker, 1974; FHWA, 1983; Potter, 1957a\&b; Talbot, 1887). Each curve was extrapolated to the 500-year event. 


\section{Description of the Water-Surface Profile Model (WSPRO) Analysis}

Datum for WSPRO analysis (USGS survey, sea level, VTAOT plans) V VTAOT plans

Datum tie between USGS survey and VTAOT plans A height of 5.3 feet was added to

the USGS' survey to obtain the datum of the VTAOT plans.

Description of reference marks used to determine USGS datum. $\quad$ BM1 is a VTAOT

metalic disk set in the top of a 12-foot diameter boulder on the upstream right bank, 15.3 feet

upstream from the right abutment (elev. $502.54 \mathrm{ft}$, arbitrary survey datum). RM2 is a spike, 6 feet

above the ground in a tree located 50 feet toward right bank from the right abutment and 17 feet

downstream from the center of the roadway (elev. $500.34 \mathrm{ft}$, arbitrary survey datum).

Cross-Sections Used in WSPRO Analysis

${ }^{1}$ For location of cross-sections see plan-view sketch included with Level I field form, Appendix E.

For more detail on how cross-sections were developed see WSPRO input file. 


\section{Data and Assumptions Used in WSPRO Model}

Hydraulic analyses of the reach were done by use of the Federal Highway Administration's WSPRO step-backwater computer program (Shearman and others, 1986, and Shearman, 1990). The analyses reported herein reflect conditions existing at the site at the time of the study. Furthermore, in the development of the model it was necessary to assume no accumulation of debris or ice at the site. Results of the hydraulic model are presented in the Bridge Hydraulic Summary, appendix B, and figure 7.

Channel roughness factors (Manning's “ $n$ ”) used in the hydraulic model were estimated using field inspections at each cross section following the general guidelines described by Arcement and Schneider (1989). Final adjustments to the values were made during the modelling of the reach. Channel " $\mathrm{n}$ " values for the reach ranged from 0.055 to 0.075 , and overbank " $n$ " values ranged from 0.050 to 0.060 .

Normal depth at the exit section (EXIT2) was assumed as the starting water surface. This depth was computed by use of the slope-conveyance method outlined in the user's manual for WSPRO (Shearman, 1990). The slope used was $0.0056 \mathrm{ft} / \mathrm{ft}$, which was estimated from the surveyed data downstream of the bridge.

The surveyed approach section (APTEM) was moved along the approach channel slope $(0.0358 \mathrm{ft} / \mathrm{ft})$ to establish the modelled approach section (APPR2), one bridge length upstream of the upstream face as recommended by Shearman and others (1986). This location provides a consistent method for determining scour variables. 


\section{Bridge Hydraulics Summary}

\begin{tabular}{llll} 
Average bridge embankment elevation & \multicolumn{2}{c}{505.8} \\
Average low steel elevation & 502.3 & $\boldsymbol{f t}$
\end{tabular}

100-year discharge $\quad 2,300 \quad \mathrm{ft}^{3} / \mathrm{s}$

Water-surface elevation in bridge opening $\quad 502.3 \quad f t$

Road overtopping? ___ Yes Discharge over road___ $885 \quad \mathrm{ft}^{3} / \mathrm{s}$

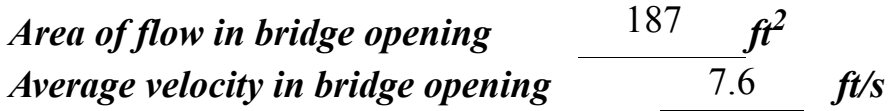

Maximum WSPRO tube velocity at bridge $\quad 9.3 \mathrm{ft} / \mathrm{s}$

Water-surface elevation at Approach section with bridge

Water-surface elevation at Approach section without bridge

504.3

Amount of backwater caused by bridge

1.1 it

500-year discharge $\quad 3,000 \quad \mathrm{ft}^{3} / \mathrm{s}$

Water-surface elevation in bridge opening

$502.3 \mathrm{ft}$

Road overtopping? ___ Yes Discharge over road ___ 1,640 $\mathrm{ft}^{3} / \mathrm{s}$

Area of flow in bridge opening

Average velocity in bridge opening 187

Maximum WSPRO tube velocity at bridge $7 t^{2}$ $2 \mathrm{ft} / \mathrm{s}$

$8.9 . / s$

Water-surface elevation at Approach section with bridge

Water-surface elevation at Approach section without bridge

Amount of backwater caused by bridge $1.0, t$

505.0

504.0

Incipient overtopping discharge $\quad 1,340 \quad \mathrm{ft}^{3} / \mathrm{s}$

Water-surface elevation in bridge opening $\quad 501.2 \quad t$

Area of flow in bridge opening $\quad 165 \quad \mathrm{ft}^{2}$

$\begin{array}{lll}\text { Average velocity in bridge opening } & 8.2 \quad \mathrm{ft} / \mathrm{s}\end{array}$

Maximum WSPRO tube velocity at bridge $\quad 10.9 \mathrm{ft} / \mathrm{s}$

Water-surface elevation at Approach section with bridge

Water-surface elevation at Approach section without bridge Amount of backwater caused by bridge 0.6 . $t$

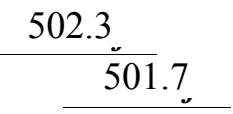




\section{Scour Analysis Summary}

\section{Special Conditions or Assumptions Made in Scour Analysis}

Scour depths were computed using the general guidelines described in Hydraulic Engineering Circular 18 (Richardson and Davis, 1995). Scour depths were calculated assuming an infinite depth of erosive material and a homogeneous particle-size distribution. The results of the scour analyses for the 100- and 500-year discharges are presented in tables 1 and 2 and the scour depths are shown graphically in figure 8 .

Contraction scour for the incipient roadway-overtopping discharges was computed by use of the Laursen clear-water contraction scour equation (Richardson and Davis, 1995, p. 32). At this site, the 100-year and 500-year discharges resulted in submerged orifice flow. Contraction scour at bridges with orifice flow is best estimated by use of the Chang pressureflow scour equation (oral communication, J. Sterling Jones, October 4, 1996). Thus, contraction scour for these discharges was computed by use of the Chang equation (Richardson and Davis, 1995, p. 145-146).

For comparison, contraction scour for the 100- and 500-year discharges also was computed by use of the Laursen clear-water contraction scour equation and the Umbrell pressure-flow equation (Richardson and Davis, 1995, p. 144). Results from these alternative computations are provided in appendix F.

Abutment scour was computed by use of the Froehlich equation (Richardson and Davis, 1995, p. 48, equation 28). Variables for the Froehlich equation include the Froude number of the flow approaching the embankments, the length of the embankment blocking flow, and the depth of flow approaching the embankment less any roadway overtopping. 


\section{Scour Results}

\section{0-yr discharge 500-yr discharge}

Contraction scour:

(Scour depths in feet)

Main channel

Live-bed scour

Clear-water scour

Depth to armoring

Left overbank

Right overbank

Local scour:

Abutment scour

Left abutment

15.2

13.0

$11.0-$

$11.6-$

$10.4-$

Right abutment

Pier scour

Pier 1

Pier 2

Pier 3

\section{Abutments:}

Left abutment

Right abutment

Piers:

Pier 1

Pier 2

\section{Riprap Sizing}

Incipient overtopping 100-yr discharge 500-yrdischarge discharge

1.2

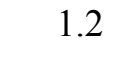

$--$
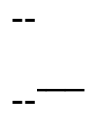
(D 50 in feet)

1.1
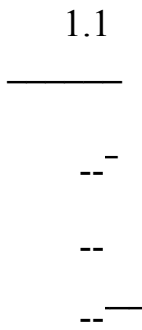

1.3

1.3 


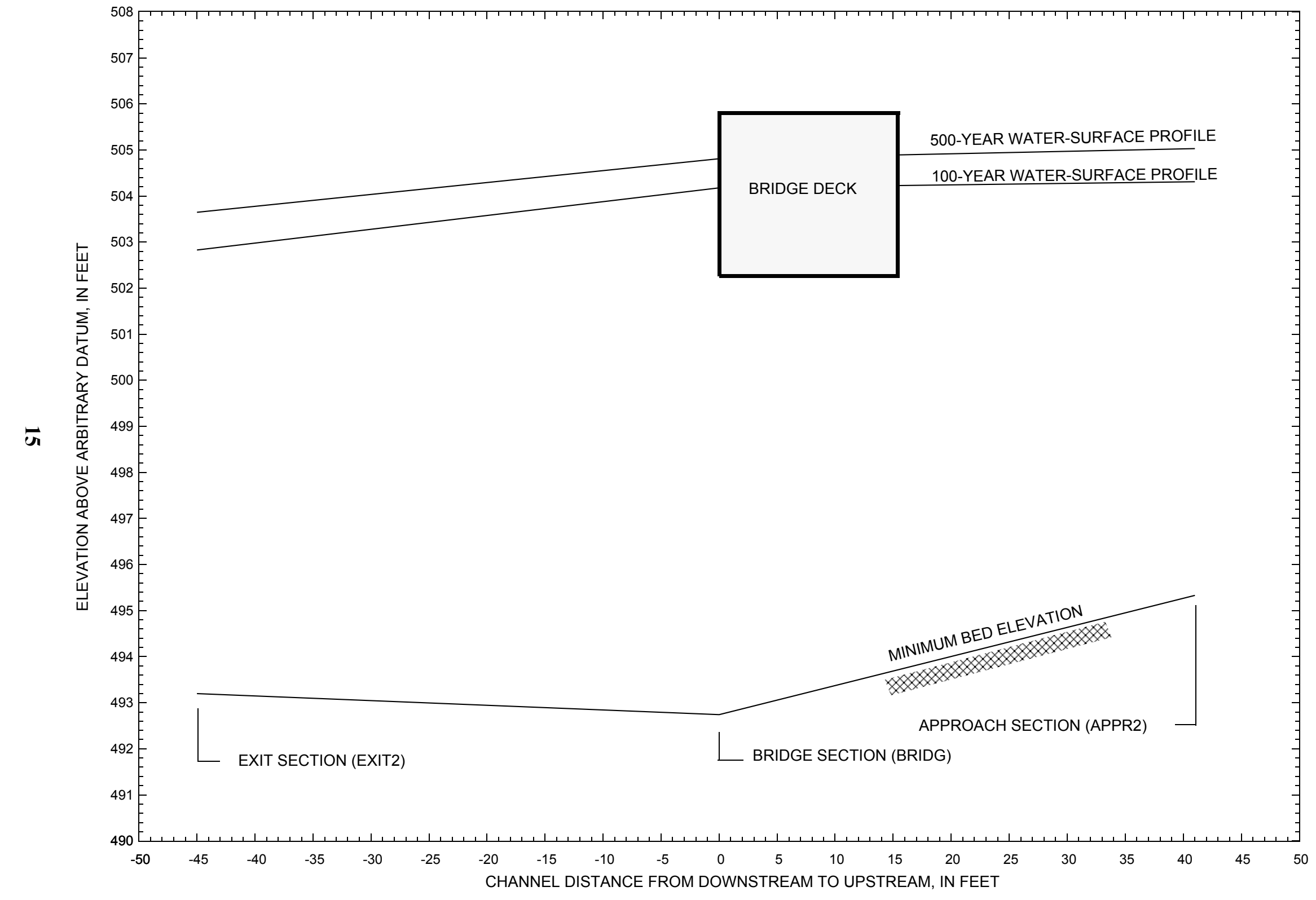

Figure 7. Water-surface profiles for the 100- and 500-year discharges at structure MENDTH00070020 on Town Highway 7, crossing Mendon Brook, Mendon, Vermont. 


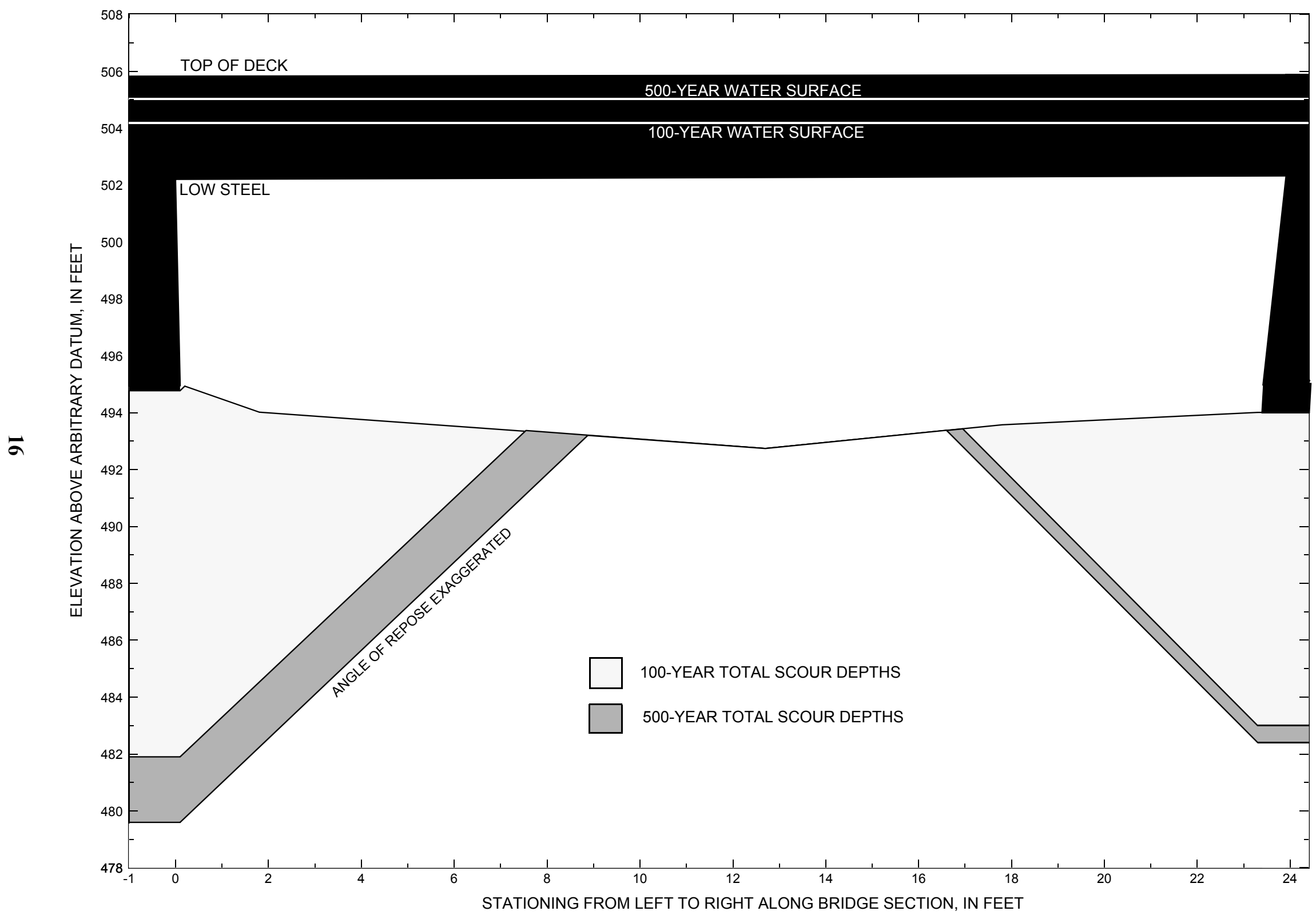

Figure 8. Scour elevations for the 100- and 500-year discharges at structure MENDTH00070020 on Town Highway 7, crossing Mendon Brook, Mendon Vermont. 
Table 1. Remaining footing/pile depth at abutments for the 100-year discharge at structure MENDTH00070020 on Town Highway 7, crossing Mendon Brook, Mendon, Vermont.

[VTAOT, Vermont Agency of Transportation; --, no data]

\begin{tabular}{|c|c|c|c|c|c|c|c|c|c|c|c|}
\hline Description & Station $^{1}$ & $\begin{array}{l}\text { VTAOT } \\
\text { minimum } \\
\text { bridge seat } \\
\text { elevation } \\
\text { (feet) }\end{array}$ & $\begin{array}{c}\text { Surveyed } \\
\text { minimum } \\
\text { low-chord } \\
\text { elevation }{ }^{2,3} \\
\text { (feet) }\end{array}$ & $\begin{array}{c}\text { Bottom of } \\
\text { footing/pile } \\
\text { elevation }{ }^{2} \\
\text { (feet) }\end{array}$ & $\begin{array}{c}\text { Channel } \\
\text { elevation at } \\
\text { abutment/ } \\
\text { pier }^{2} \\
\text { (feet) }\end{array}$ & $\begin{array}{l}\text { Contraction } \\
\text { scour depth } \\
\text { (feet) }\end{array}$ & $\begin{array}{l}\text { Abutment } \\
\text { scour } \\
\text { depth } \\
\text { (feet) }\end{array}$ & $\begin{array}{l}\text { Pier } \\
\text { scour } \\
\text { depth } \\
\text { (feet) }\end{array}$ & $\begin{array}{l}\text { Depth of } \\
\text { total scour } \\
\text { (feet) }\end{array}$ & $\begin{array}{c}\text { Elevation of } \\
\text { scour }^{2} \\
\text { (feet) }\end{array}$ & $\begin{array}{c}\text { Remaining } \\
\text { footing/pile } \\
\text { depth } \\
\text { (feet) }\end{array}$ \\
\hline \multicolumn{12}{|c|}{100 -year discharge is 2,300 cubic-feet per second } \\
\hline Left abutment & 0.0 & 502.2 & 502.2 & 494.8 & 494.8 & 0.0 & 12.9 & -- & 12.9 & 481.9 & -12.9 \\
\hline Right abutment & 23.4 & 502.2 & 502.3 & 494.0 & 494.0 & 0.0 & 11.0 & -- & 11.0 & 483.0 & -11.0 \\
\hline
\end{tabular}

1.Measured along the face of the most constricting side of the bridge.

2.Arbitrary datum for this study.

3.Low-chord elevations are the same as bridge seat elevations

Table 2. Remaining footing/pile depth at abutments for the 500-year discharge at structure MENDTH00070020 on Town Highway 7, crossing Mendon Brook, Mendon, Vermont.

[VTAOT, Vermont Agency of Transportation; --, no data]

\begin{tabular}{|c|c|c|c|c|c|c|c|c|c|c|c|}
\hline Description & Station $^{1}$ & $\begin{array}{c}\text { VTAOT } \\
\text { minimum } \\
\text { bridge seat } \\
\text { elevation } \\
\text { (feet) }\end{array}$ & $\begin{array}{c}\text { Surveyed } \\
\text { minimum } \\
\text { low-chord } \\
\text { elevation }{ }^{2,3} \\
\text { (feet) }\end{array}$ & $\begin{array}{c}\text { Bottom of } \\
\text { footing/pile } \\
\text { elevation }{ }^{2} \\
\text { (feet) }\end{array}$ & $\begin{array}{c}\text { Channel } \\
\text { elevation at } \\
\text { abutment/ } \\
\text { pier }^{2} \\
\text { (feet) }\end{array}$ & $\begin{array}{l}\text { Contraction } \\
\text { scour depth } \\
\text { (feet) }\end{array}$ & $\begin{array}{l}\text { Abutment } \\
\text { scour } \\
\text { depth } \\
\text { (feet) }\end{array}$ & $\begin{array}{l}\text { Pier } \\
\text { scour } \\
\text { depth } \\
\text { (feet) }\end{array}$ & $\begin{array}{l}\text { Depth of } \\
\text { total scour } \\
\text { (feet) }\end{array}$ & $\begin{array}{c}\text { Elevation of } \\
\text { scour }^{2} \\
\text { (feet) }\end{array}$ & $\begin{array}{c}\text { Remaining } \\
\text { footing/pile } \\
\text { depth } \\
\text { (feet) }\end{array}$ \\
\hline \multicolumn{12}{|c|}{500 -year discharge is 3,000 cubic-feet per second } \\
\hline Left abutment & 0.0 & 502.2 & 502.2 & 494.8 & 494.8 & 0.0 & 15.2 & -- & 15.2 & 479.6 & -15.2 \\
\hline Right abutment & 23.4 & 502.2 & 502.3 & 494.0 & 494.0 & 0.0 & 11.6 & -- & 11.6 & 482.4 & -11.6 \\
\hline
\end{tabular}

1.Measured along the face of the most constricting side of the bridge.

2.Arbitrary datum for this study.

3. Low-chord elevations are the same as bridge seat elevations 


\section{SELECTED REFERENCES}

Arcement, G.J., Jr., and Schneider, V.R., 1989, Guide for selecting Manning's roughness coefficients for natural channels and flood plains: U.S. Geological Survey Water-Supply Paper 2339, 38 p.

Barnes, H.H., Jr., 1967, Roughness characteristics of natural channels: U.S. Geological Survey Water-Supply Paper 1849,213 p.

Benson, M. A., 1962, Factors Influencing the Occurrence of Floods in a Humid Region of Diverse Terrain: U.S. Geological Survey WaterSupply Paper 1580-B, 64 p.

Brown, S.A. and Clyde, E.S., 1989, Design of riprap revetment: Federal Highway Administration Hydraulic Engineering Circular No. 11, Publication FHWA-IP-89-016, 156 p.

Federal Highway Administration, 1983, Runoff estimates for small watersheds and development of sound design: Federal Highway Administration Report FHWA-RD-77-158.

Federal Highway Administration, 1993, Stream Stability and Scour at Highway Bridges: Participant Workbook: Federal Highway Administration Report FHWA-HI-91-011.

Froehlich, D.C., 1989, Local scour at bridge abutments in Ports, M.A., ed., Hydraulic Engineering--Proceedings of the 1989 National Conference on Hydraulic Engineering: New York, American Society of Civil Engineers, p. 13-18.

Hayes, D.C.,1993, Site selection and collection of bridge-scour data in Delaware, Maryland, and Virginia: U.S. Geological Survey WaterResources Investigation Report 93-4017, 23 p.

Interagency Advisory Committee on Water Data, 1982, Guidelines for determining flood flow frequency: U.S. Geological Survey, Bulletin 17B of the Hydrology Subcommittee, 190 p.

Johnson, C.G. and Tasker, G.D.,1974, Progress report on flood magnitude and frequency of Vermont streams: U.S. Geological Survey OpenFile Report 74-130, 37 p.

Lagasse, P.F., Schall, J.D., Johnson, F., Richardson, E.V., Chang, F., 1995, Stream Stability at Highway Structures: Federal Highway Administration Hydraulic Engineering Circular No. 20, Publication FHWA-IP-90-014, 144 p.

Laursen, E.M., 1960, Scour at bridge crossings: Journal of the Hydraulics Division, American Society of Civil Engineers, v. 86, no. HY2, p. 39-53.

Potter, W. D., 1957a, Peak rates of runoff in the Adirondack, White Mountains, and Maine woods area, Bureau of Public Roads

Potter, W. D., 1957b, Peak rates of runoff in the New England Hill and Lowland area, Bureau of Public Roads

Richardson, E.V. and Davis, S.R., 1995, Evaluating scour at bridges: Federal Highway Administration Hydraulic Engineering Circular No. 18, Publication FHWA-IP-90-017, 204 p.

Richardson, E.V., Simons, D.B., and Julien, P.Y., 1990, Highways in the river environment: Federal Highway Administration Publication FHWA-HI-90-016.

Ritter, D.F., 1984, Process Geomorphology: W.C. Brown Co., Debuque, Iowa, 603 p.

Shearman, J.O., 1990, User's manual for WSPRO--a computer model for water surface profile computations: Federal Highway Administration Publication FHWA-IP-89-027, 187 p.

Shearman, J.O., Kirby, W.H., Schneider, V.R., and Flippo, H.N., 1986, Bridge waterways analysis model; research report: Federal Highway Administration Publication FHWA-RD-86-108, 112 p.

Talbot, A.N., 1887, The determination of water-way for bridges and culverts.

U.S. Geological Survey, Chittendon, 1961, Vermont 7.5 Minute Series quadrangle map: U.S. Geological Survey Topographic Maps, Photorevised 1988, Scale 1:24,000. 


\section{APPENDIX A: \\ WSPRO INPUT FILE}




\section{WSPRO INPUT FILE}

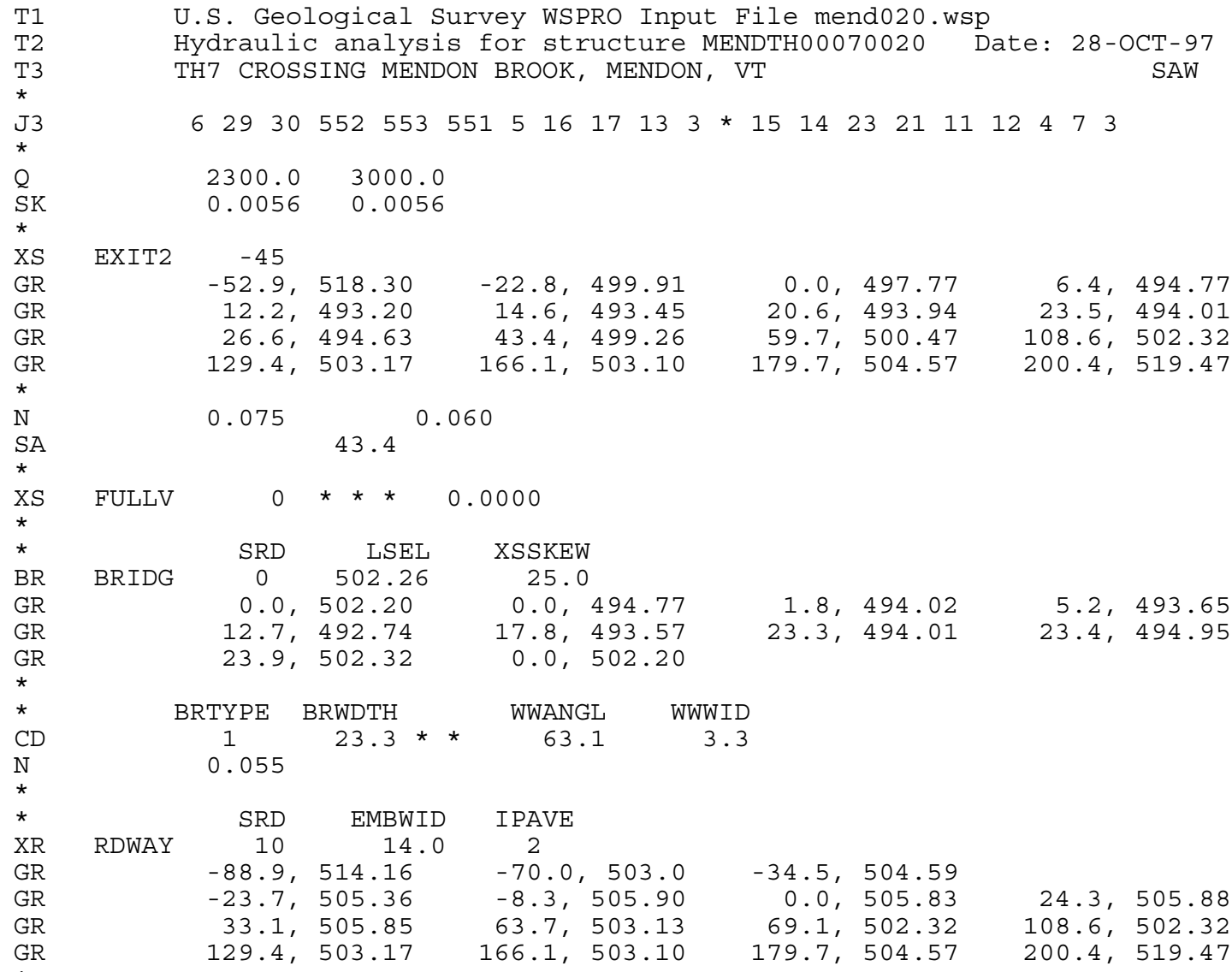

For the incipient overtopping discharge the section below was truncated at station -34.0 to keep WSPRO from modeling flow on the left overbank, which is separated from the main channel flow.

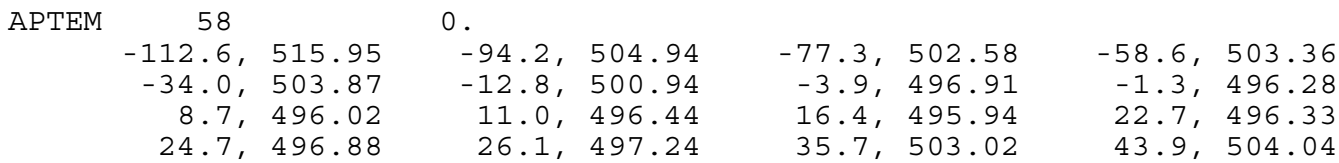




\section{APPENDIX B: \\ WSPRO OUTPUT FILE}


WSPRO OUTPUT FILE

$\begin{array}{lcl}\text { WSPRO } & \text { FEDERAL HIGHWAY ADMINISTRATION - U. S. GEOLOGICAL SURVEY } \\ \text { V060188 } & \text { MODEL FOR WATER-SURFACE PROFILE COMPUTATIONS }\end{array}$

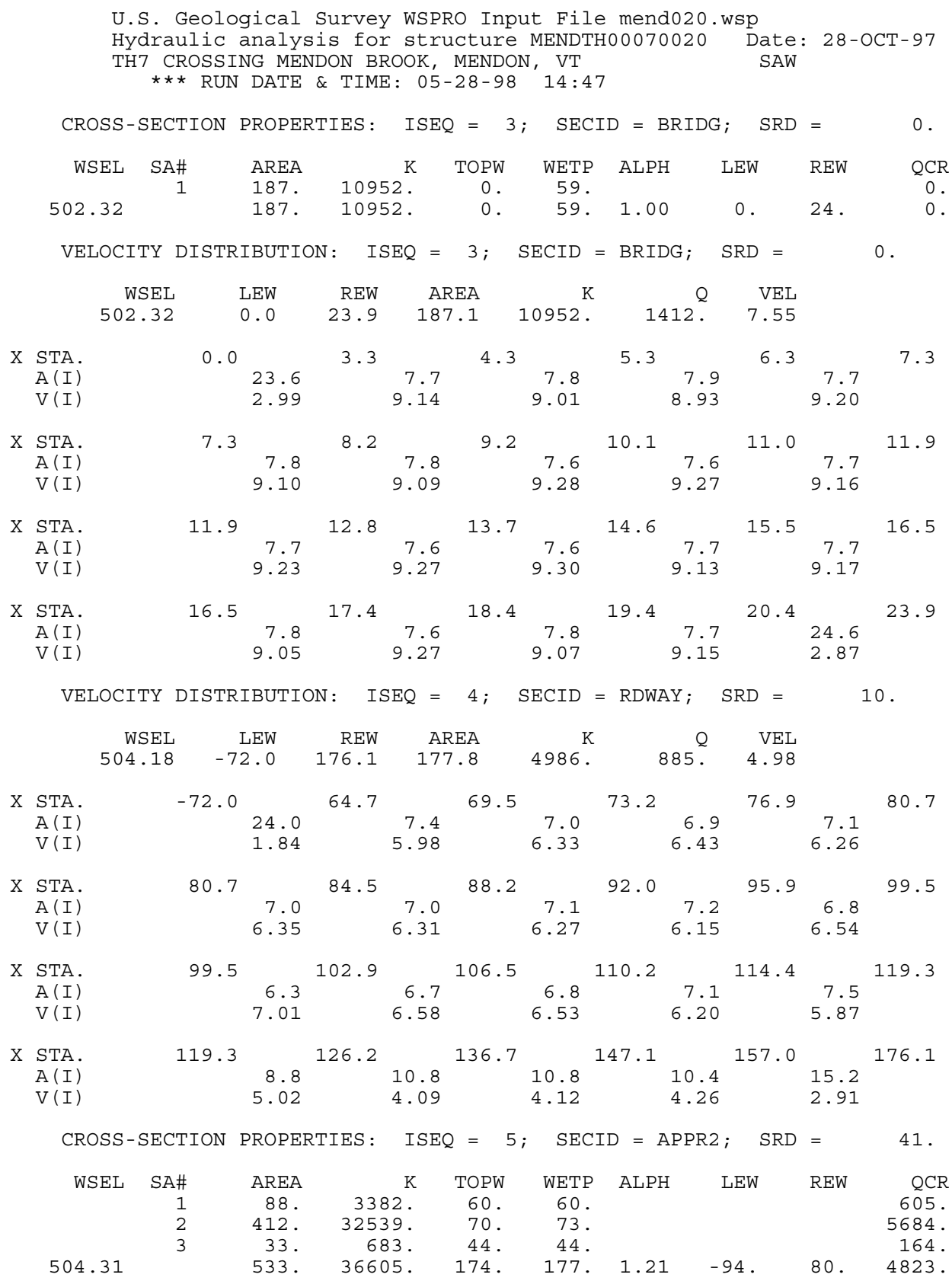

VELOCITY DISTRIBUTION: ISEQ = 5; SECID = APPR2; $\quad$ SRD $=$

41.

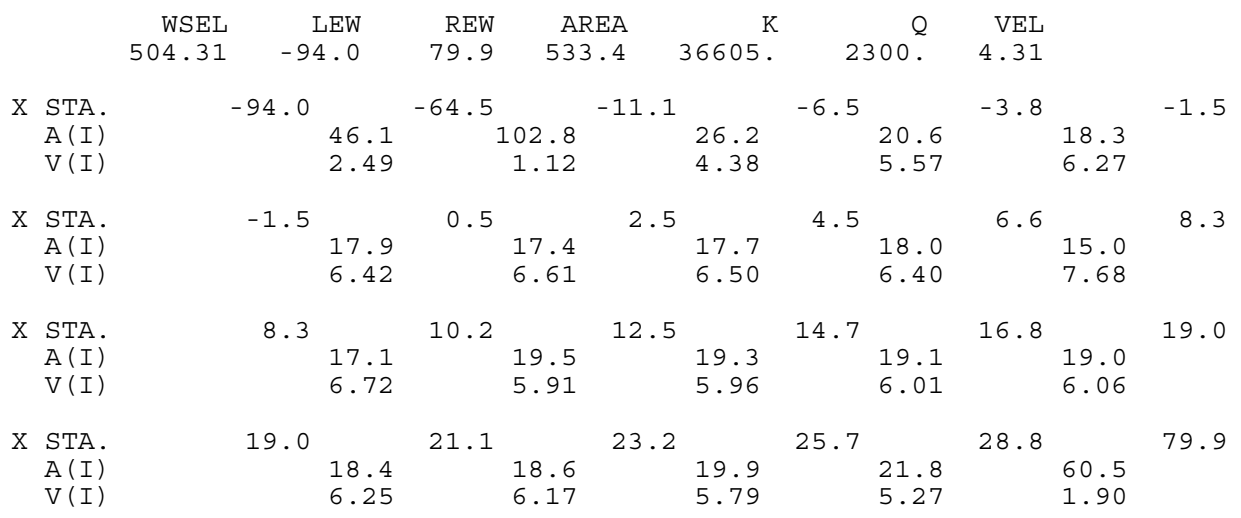




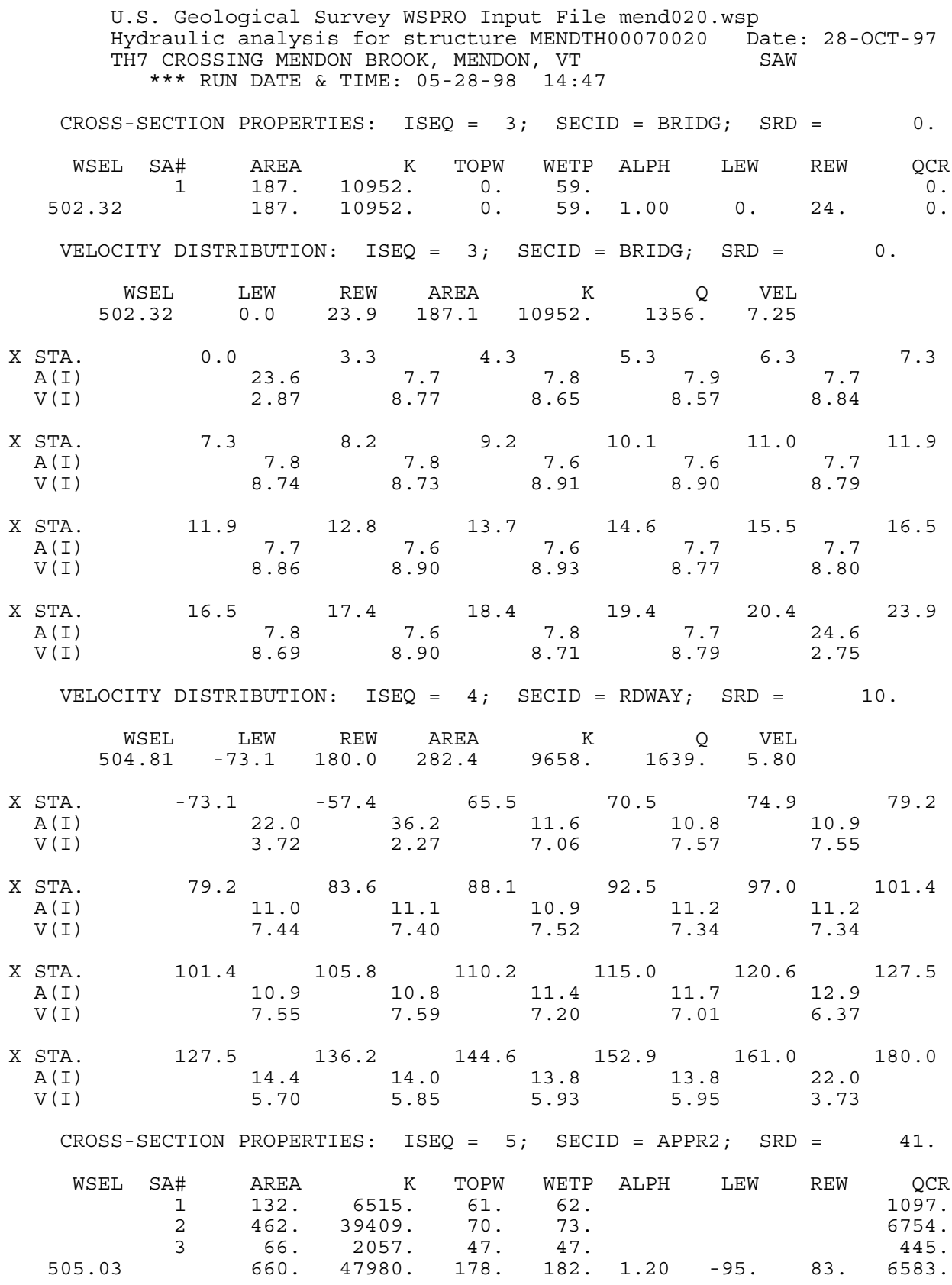

VELOCITY DISTRIBUTION: $\quad$ ISEQ $=5 ; \operatorname{SECID~}=$ APPR2; $\quad$ SRD $=$

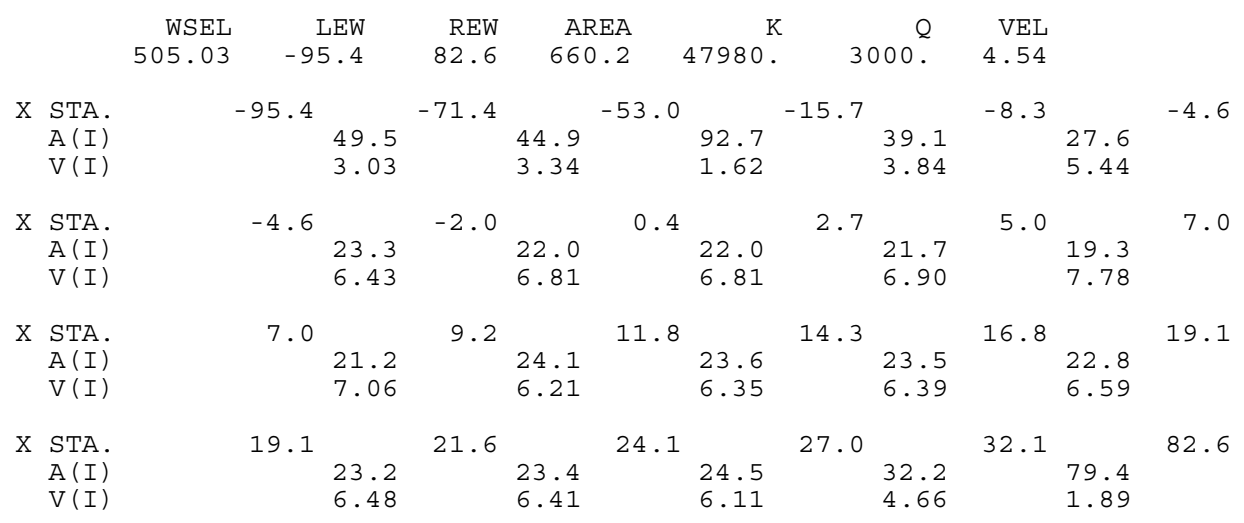


WSPRO OUTPUT FILE (continued)

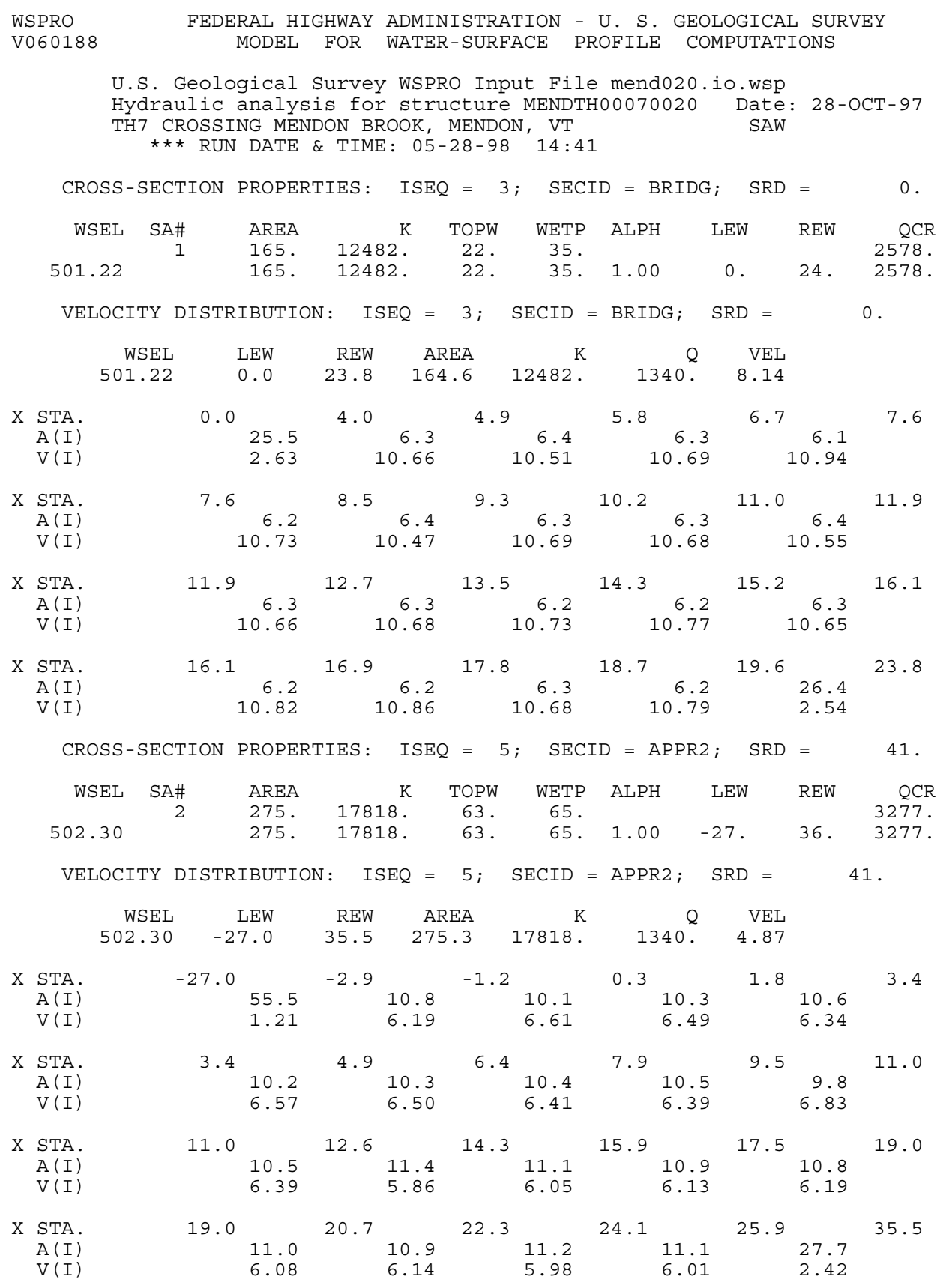


WSPRO OUTPUT FILE (continued)

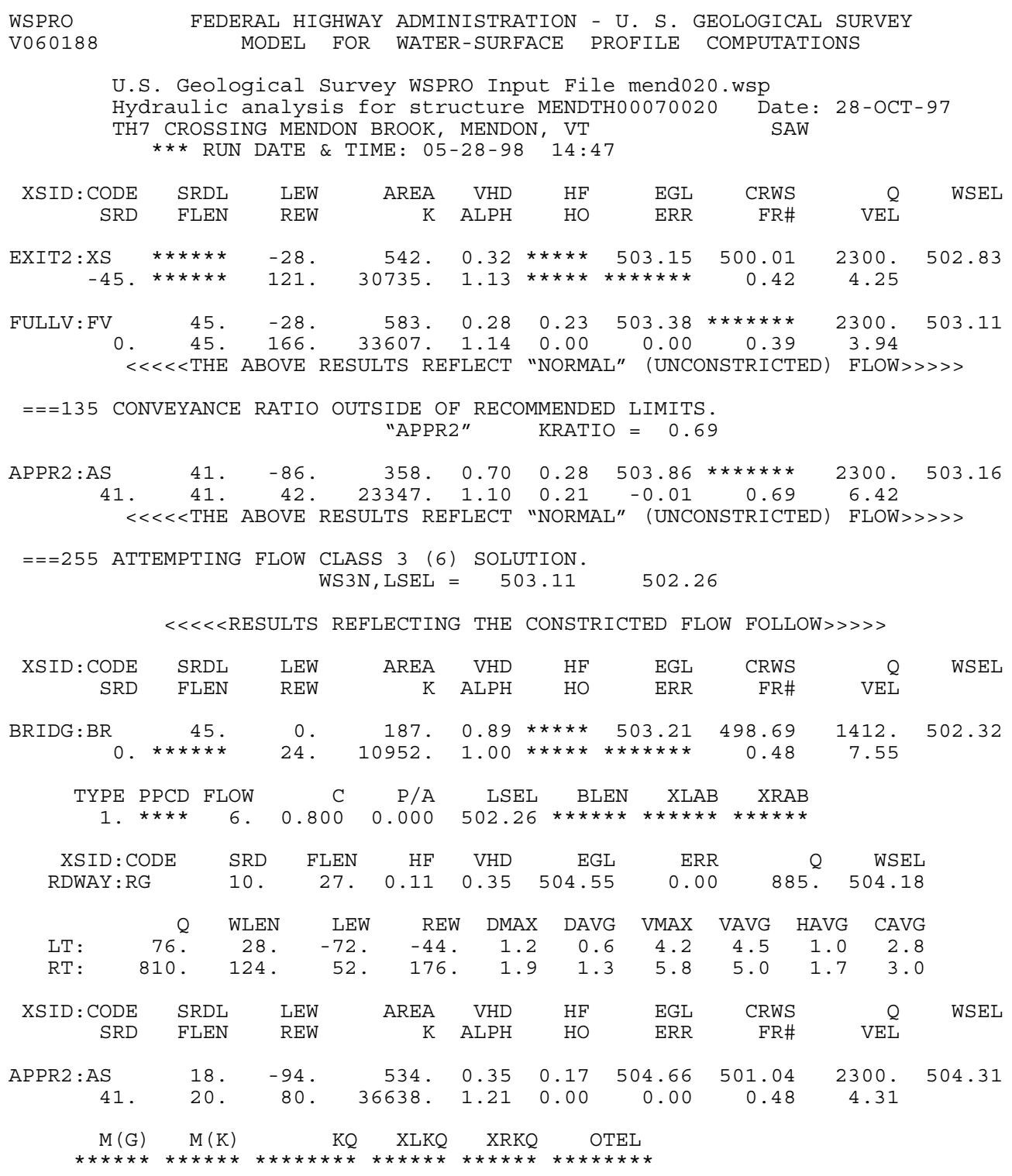

$<<<<$ END OF BRIDGE COMPUTATIONS $>>>>>$

FIRST USER DEFINED TABLE.

\begin{tabular}{|c|c|c|c|c|c|c|c|c|}
\hline XSID : CODE & SRD & LEW & REW & $Q$ & K & AREA & VEL & WSEL \\
\hline EXIT2:XS & -45 & -28 & 121. & 2300 . & 30735 & 542 . & 4.25 & 502.83 \\
\hline FULLV : FV & 0 . & -28 & 166. & 2300 . & 33607 . & 583. & 3.94 & 503.11 \\
\hline BRIDG : BR & 0 . & 0 & 24 & 1412 . & 10952 . & 187. & 7.55 & 502.32 \\
\hline RDWAY : RG & 10. & $\star \star \star * *$ & 76. & 885 . & $\star \star \star \star \star \star \star * \star *$ & $* \star * * *$ & 2.00 & 504.18 \\
\hline APPR2 : AS & 41. & -94 & 80. & 2300. & 36638 . & 534. & 4.31 & 504.31 \\
\hline XSID : CODE & XLKQ & $\mathrm{XRKQ}$ & & & & & & \\
\hline
\end{tabular}

SECOND USER DEFINED TABLE.

\begin{tabular}{|c|c|c|c|c|c|c|c|c|}
\hline XSID : CODE & CRWS & FR\# & YMIN & YMAX & $\mathrm{HO}$ & VHD & EGL & WSEL \\
\hline EXIT2:XS & 500.01 & 0.42 & 493.20 & $519.47 *$ & 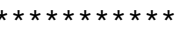 & 0.32 & 503.15 & 502.83 \\
\hline FULLV : FV & 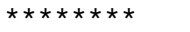 & 0.39 & 493.20 & 519.47 & 0.23 & 0.28 & 503.38 & 503.11 \\
\hline BRIDG : BR & 498.69 & 0.48 & 492.74 & $502.32 *$ & 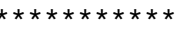 & 0.89 & 503.21 & 502.32 \\
\hline RDWAY : RG & 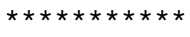 & $\star \star \star \star \star *$ & 502.32 & 519.47 & $0.11 * \star \star \star \star \star * \star$ & 0.35 & 504.55 & 504.1 \\
\hline APPR2 : AS & 501.04 & 0.48 & 495.33 & 521.28 & 0.17 & 0.35 & 504.66 & 504.3 \\
\hline
\end{tabular}


WSPRO OUTPUT FILE (continued)

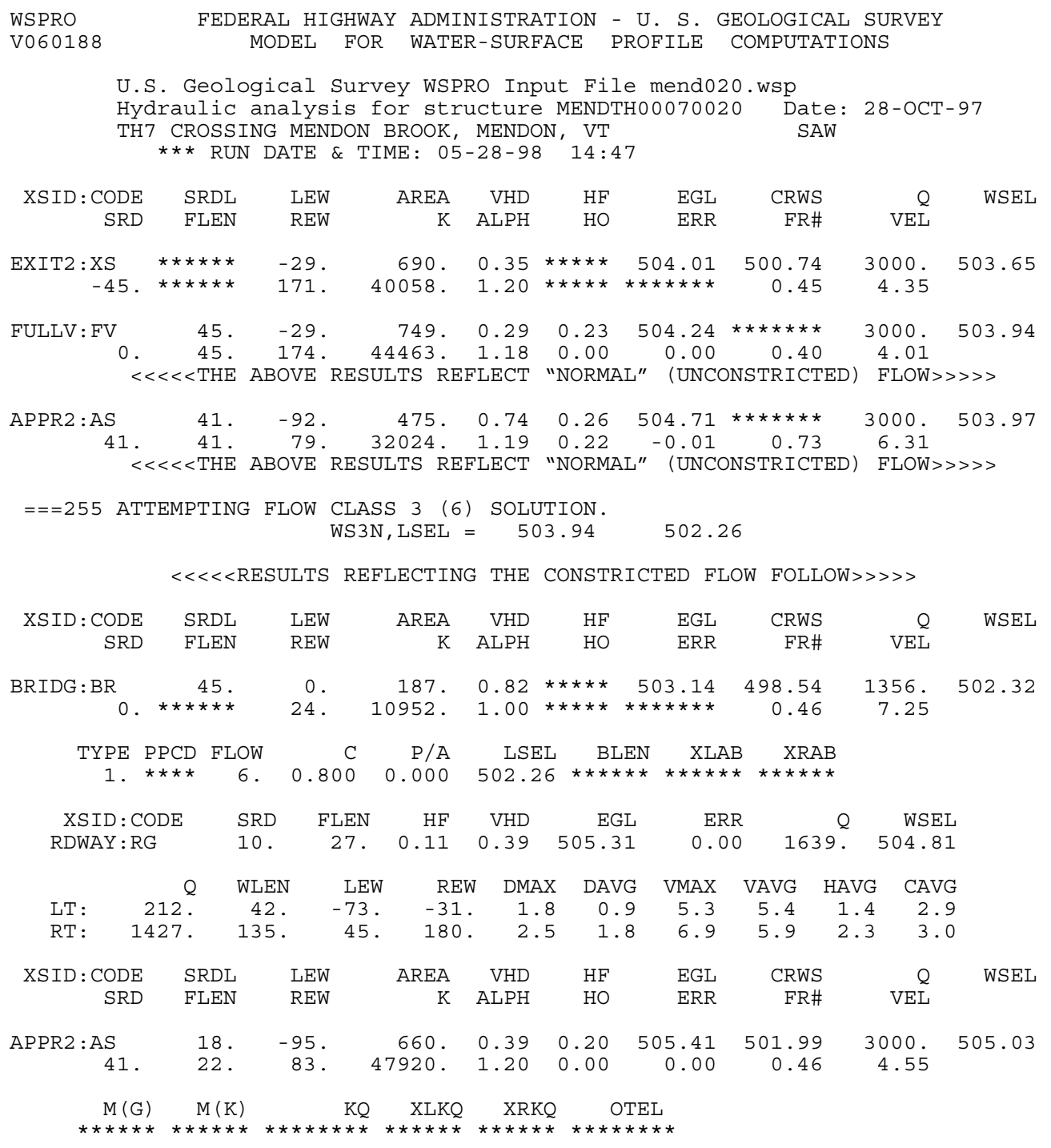

FIRST USER DEFINED TABLE.

\begin{tabular}{|c|c|c|c|c|c|c|c|c|}
\hline XSID:CODE & SRD & LEW & REW & $Q$ & $\mathrm{~K}$ & AREA & VEL & WSEL \\
\hline EXIT2:XS & -45 . & -29 & 171. & 3000 & 40058 . & 690. & 4.35 & 503.65 \\
\hline FULLV : FV & 0 . & -29 . & 174. & 3000 & 44463 . & 749 . & 4.01 & 503.94 \\
\hline BRIDG : BR & 0 . & 0. & 24 . & 1356 & 10952. & 187. & 7.25 & 502.32 \\
\hline RDWAY : RG & $10 . *$ & $\star \star \star \star \star *$ & 212 . & 1639. & 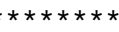 & $\star \star \star \star \star *$ & 2.00 & 504.81 \\
\hline APPR2 : AS & 41. & -95. & 83. & 3000 & 47920 . & 660. & 4.55 & 505.03 \\
\hline
\end{tabular}

SECOND USER DEFINED TABLE.

\begin{tabular}{|c|c|c|c|c|c|c|c|c|c|}
\hline XSID : CODE & CRWS & FR\# & YMIN & YMAX & $\mathrm{HF}$ & $\mathrm{HO}$ & VHD & EGL & WSEL \\
\hline EXIT2:XS & 500.74 & 0.45 & 493.20 & 519.47 * & $\star \star \star \star \star \star \star$ & 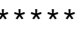 & 0.35 & 504.01 & 503.65 \\
\hline FULLV : FV & 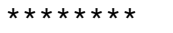 & 0.40 & 493.20 & 519.47 & 0.23 & 0.00 & 0.29 & 504.24 & 503.94 \\
\hline BRIDG : BR & 498.54 & 0.46 & 492.74 & $502.32 *$ & 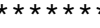 & 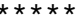 & 0.82 & 503.14 & 502.32 \\
\hline RDWAY : RG & 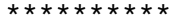 & $\star \star \star \star \star \star$ & 502.32 & 519.47 & $0.11 *$ & 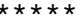 & 0.39 & 505.31 & 504.81 \\
\hline APPR2 : AS & 501.99 & 0.46 & 495.33 & 521.28 & 0.20 & 0.00 & 0.39 & 505.41 & 505.03 \\
\hline
\end{tabular}


WSPRO OUTPUT FILE (continued)

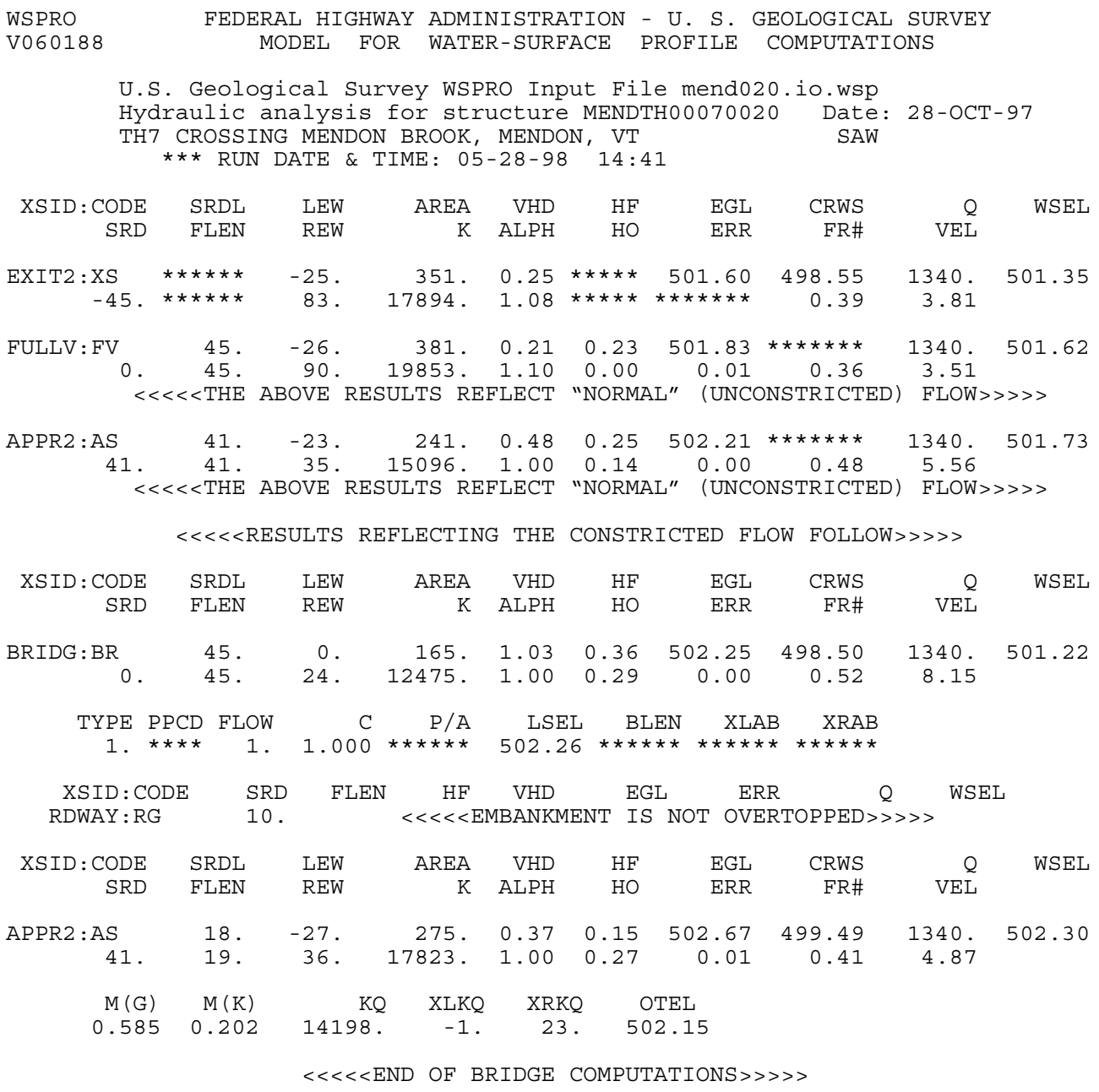

FIRST USER DEFINED TABLE.

\begin{tabular}{|c|c|c|c|c|c|c|c|c|}
\hline XSID : CODE & SRD & LEW & REW & $Q$ & $\mathrm{~K}$ & AREA & VEL & WSEL \\
\hline EXIT2:XS & -45 & -25 & 83. & 1340 . & 17894. & 351. & 3.81 & 501.35 \\
\hline FULLV : FV & 0 . & -26 & 90. & 1340. & 19853. & 381. & 3.51 & 501.62 \\
\hline BRIDG : BR & 0. & 0. & 24. & 1340. & 12475 . & 165. & 8.15 & 501.22 \\
\hline RDWAY : RG & \multicolumn{3}{|c|}{$10 . * * \star * \star * \star * \star * \star * \star * \star * *$} & \multicolumn{3}{|c|}{ 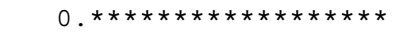 } & \multicolumn{2}{|c|}{$2.00 * * \star * * * * *$} \\
\hline APPR2 : AS & 41 & -27 & 36. & 1340. & 17823. & 275 . & 4.87 & 502.30 \\
\hline XSID : CODE & XLKQ & XRKQ & & & & & & \\
\hline APPR2 : AS & -1 . & 23. & 1419 & & & & & \\
\hline
\end{tabular}

SECOND USER DEFINED TABLE.

\begin{tabular}{|c|c|c|c|c|c|c|c|c|c|}
\hline XSID : CODE & CRWS & FR\# & YMIN & YMAX & $\mathrm{HF}$ & $\mathrm{HO}$ & VHD & EGL & WSEL \\
\hline EXIT2:XS & 498.55 & 0.39 & 493.20 & $519.47 * *$ & 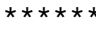 & $\star \star \star \star \star *$ & 0.25 & 501.60 & 501.35 \\
\hline FULLV : FV & 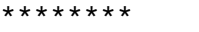 & 0.36 & 493.20 & 519.47 & 0.23 & 0.00 & 0.21 & 501.83 & 501.62 \\
\hline BRIDG : BR & 498.50 & 0.52 & 492.74 & 502.32 & 0.36 & 0.29 & 1.03 & 502.25 & 501.22 \\
\hline RDWAY : RG & 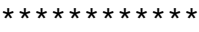 & $\star \star \star \star$ & 502.32 & $519.47 * *$ & $\star \star \star \star \star *$ & $\star \star \star \star \star \star \star$ & $\star \star \star \star \star *$ & $\star \star$ & $x *$ \\
\hline APPR2 : AS & 499.49 & 0.41 & 495.33 & 521.28 & 0.15 & 0.27 & 0.37 & 502.67 & 502.3 \\
\hline
\end{tabular}




\section{APPENDIX C:}

\section{BED-MATERIAL PARTICLE-SIZE DISTRIBUTION}




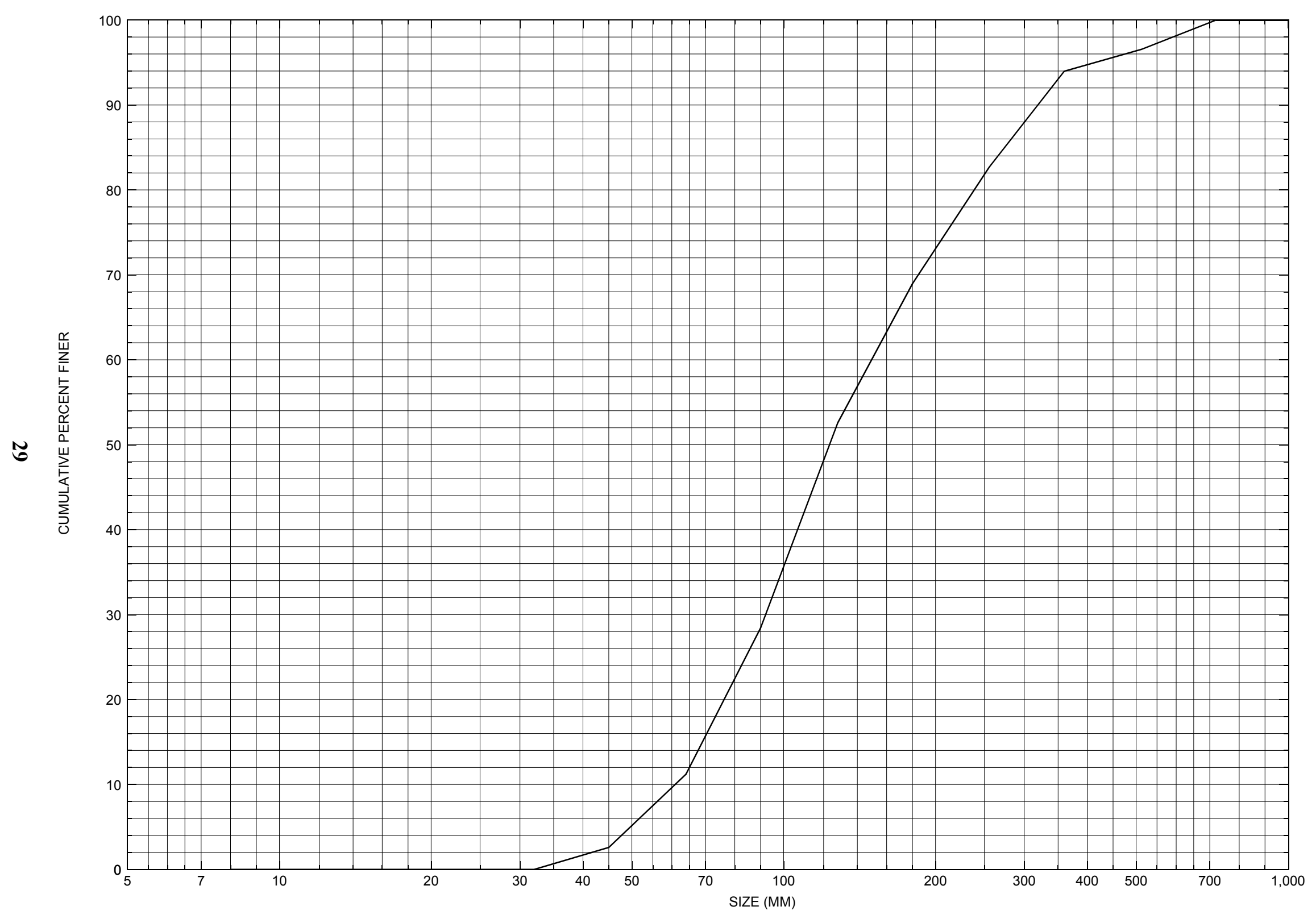

Appendix C. Bed material particle-size distribution for a pebble count in the channel approach of structure MENDTH00070020 in Mendon, Vermont. 


\section{APPENDIX D: \\ HISTORICAL DATA FORM}




\section{Structure Number MENDTH00070020}

\section{General Location Descriptive}

Data collected by (First Initial, Full last name) $\mathbf{E}$. BOEHMLER

Date $(M M / D D / Y Y) \_\mathbf{0 3} / \underline{13} / \underline{95}$

Highway District Number (I - 2; nn) $\mathbf{0 3}$

Town (FIPS place code; I - 4; nnnnn) $\mathbf{4 4 1 2 5}$

Waterway (I - 6) MENDON BROOK

Route Number $\underline{\text { TH007 }}$

Topographic Map Chittenden

Latitude (I - 16; nnnn.n) $\mathbf{4 3 3 8 5}$
County (FIPS county code; I - 3; nnn)

Mile marker (I - 11; nnn.nnn) $\mathbf{0 0 0 0 0 0}$

Road Name (I - 7): -

Vicinity (I - 9) 0.7 MI TO JCT W US4

Hydrologic Unit Code: $\mathbf{0 2 0 1 0 0 0 2}$

Longitude (i - 17; nnnnn.n) $\mathbf{7 2 5 3 6}$

\section{Select Federal Inventory Codes}

FHWA Structure Number (I - 8) 10111000201110

Maintenance responsibility $(I-21 ; n n) \quad \mathbf{0 3}$

Year built (I - 27; YYYY) 1962

Average daily traffic, ADT (I - 29; nnnnnn) 000080

Year of ADT (I - 30; YY) $\mathbf{9 1}$

Opening skew to Roadway $(I-34 ; n n) \quad 18$

Operational status $(I-41 ; X) \mathbf{R}$

Structure type (I - 43; nnn) $\mathbf{3 0 2}$

Approach span structure type (I - 44; nnn) $\mathbf{0 0 0}$

Number of spans (I - 45; nnn) $\mathbf{0 0 1}$

Number of approach spans (I - 46; nnnn) $\mathbf{0 0 0 0}$

Comments:

The structural inspection report of 9/10/93 indicates the structure is a steel stringer type bridge with a concrete deck. The abutments and wingwalls are concrete. The wingwalls are short in length. The right abutment and its wingwalls are noted as undermined up to 3 feet over the entire length of each with a penetration up to 8 inches beneath. The ends of both right wingwalls and the right abutment at the centerline of the roadway are resting on boulders. The left abutment also is undermined up to 30 inches for most of its length with penetration reaching 3 to 4 inches. Most of the channel flow is against the right abutment currently. Boulder riprap protection has been placed around the ends of the right (Continued, page 33) 


\section{Bridge Hydrologic Data}

Is there hydrologic data available? $\mathbf{N}$ if No, type ctrl- $n$ VTAOT Drainage area $\left(\mathrm{mi}^{2}\right)^{2}$ : -

Terrain character:

Stream character \& type: -

Streambed material: Sand and gravel with random boulders

Discharge Data (cfs): $\quad Q_{2.33}-$

$$
\mathrm{Q}_{50}
$$

$$
\begin{aligned}
& Q_{25} \ldots \\
& Q_{500}-
\end{aligned}
$$

Record flood date (MM /DD/YY): -

Water surface elevation (ft): -

Estimated Discharge (cfs): Velocity at $\mathrm{Q}$ $(\mathrm{ft} / \mathrm{s}):$

Ice conditions (Heavy, Moderate, Light) : -

Debris (Heavy, Moderate, Light):

The stage increases to maximum highwater elevation (Rapidly, Not rapidly):

The stream response is (Flashy, Not flashy):

Describe any significant site conditions upstream or downstream that may influence the stream's stage: -

Watershed storage area (in percent): - _ \%

The watershed storage area is: - _ (1-mainly at the headwaters; 2- uniformly distributed; 3-immediatly upstream oi the site)

Water Surface Elevation Estimates for Existing Structure:

\begin{tabular}{|l|l|l|l|l|l|}
\hline Peak discharge frequency & $Q_{2.33}$ & $Q_{10}$ & $Q_{25}$ & $Q_{50}$ & $Q_{100}$ \\
Water surface elevation (ft)) & - & - & - & - & - \\
Velocity (ft/sec) & - & - & - & - & - \\
\hline
\end{tabular}

Long term stream bed changes: -

Is the roadway overtopped below the $\mathrm{Q}_{100}$ ? (Yes, No, Unknown): $\mathbf{U} \quad$ Frequency: Relief Elevation $(f t)$ : Discharge over roadway at $Q_{100}\left(f^{3} / \mathrm{sec}\right)$ :

Are there other structures nearby? (Yes, No, Unknown): Upstream distance (miles): Town: If No or Unknown, type ctrl-n os Highway No. : Structure No. : Year Built:

Clear span (ft): Clear Height (ft): Full Waterway $\left(f t^{2}\right)$ : 
Downstream distance (miles): Town: Year Built:

Highway No. : Structure No. : Structure Type:

Clear span (ft): Clear Height $(f t)$ : Full Waterway $\left(f^{2}\right)$ :

Comments:

wingwalls. There is natural boulder riprap noted along the channel boundaries up- and downstream of the bridge. The bridge is open to very restricted traffic, with a sign that states "Bridge Closed - Pass at own risk".

\section{USGS Watershed Data}

Watershed Hydrographic Data

Drainage area (DA) 11.87

Watershed storage (ST) $\mathrm{mi}^{2}$

Bridge site elevation

$$
1390
$$
$\mathrm{mi}^{2}$ 1390 $\mathrm{ft}$ $\%$

Main channel length $\mathbf{5 . 8 1}$ mi $10 \%$ channel length elevation $\mathbf{1 4 5 0}$ $\mathrm{ft} \quad 85 \%$ channel length elevation 2700 $\mathrm{ft}$

Main channel slope (S) $\quad \mathbf{2 8 6 . 8 7} \mathrm{ft} / \mathrm{mi}$

Watershed Precipitation Data

Average site precipitation in Average headwater precipitation in

Maximum 2yr-24hr precipitation event $(124,2)$ in

Average seasonal snowfall (Sn) $\mathrm{ft}$ 


\section{Bridge Plan Data}

Are plans available? $\underline{Y}$ If no, type ctrl-n pl Date issued for construction (MM/YYYY): 06 / 1963 Project Number TF 16-1963

Low superstructure elevation: USLAB $\mathbf{5 0 2 . 2}$ DSLAB $\mathbf{5 0 2 . 2}$ Minimum channel bed elevation: 498.7

Benchmark location description:

BM\#1, [spike in trunk or root of] a 4 inch elm tree located about 75 feet right bankward from the right abutment and about 17 feet perpendicular from the centerline of the roadway in a downstream direction, Elevation 500.00.

Reference Point (MSL, Arbitrary, Other): Arbitrary Datum (NAD27, NAD83, Other): Arbitrary Foundation Type: 1 (1-Spreadfooting; 2-Pile; 3- Gravity; 4-Unknown)

If 1: Footing Thickness $\mathbf{2 . 5} \quad$ Footing bottom elevation: $\underline{494.7}$

If 2: Pile Type:___ (1-Wood; 2-Steel or metal; 3-Concrete) Approximate pile driven length:

If 3: Footing bottom elevation:

Is boring information available? $\mathbf{N}$ If no, type ctrl- $n$ bi Number of borings taken: _-

Foundation Material Type: $\mathbf{3}$ (1-regolith, 2-bedrock, 3-unknown)

Briefly describe material at foundation bottom elevation or around piles:

$-$

Comments:

Under the current conditions where both abutments are undermined, the footing at this bridge is indicated in the structural report to be boulders. These bridge plans are listed under the project number TF16/1963. Note: The proposed streambed was graded level under the bridge at elevation 498.7, which is about 4 feet above the bottom of the footings or about 1.5 feet above the top of the footings.

Note: The bridge seat and low superstructure elevation are the same for this bridge.

$\mathbf{N}$ 


\section{Cross-sectional Data}

Is cross-sectional data available? If no, type ctrl-n xs

Source (FEMA, VTAOT, Other)? NO Comments:

\section{CROSS SECTION INFORMATION}

\begin{tabular}{|l|l|l|l|l|l|l|l|l|l|l|l|}
\hline Station & - & - & - & - & - & - & - & - & - & - & - \\
\hline Feature & - & - & - & - & - & - & - & - & - & - & - \\
\hline $\begin{array}{l}\text { Low chord } \\
\text { elevation }\end{array}$ & - & - & - & - & - & - & - & - & - & - & - \\
\hline $\begin{array}{l}\text { Bed } \\
\text { elevation }\end{array}$ & - & - & - & - & - & - & - & - & - & - & - \\
\hline $\begin{array}{l}\text { Low chord } \\
\text { to bed }\end{array}$ & - & - & - & - & - & - & - & - & - & - & - \\
\hline Station & - & - & - & - & - & - & - & - & - & - & - \\
\hline Feature & - & - & - & - & - & - & - & - & - & - & - \\
\hline $\begin{array}{l}\text { Low chord } \\
\text { elevation }\end{array}$ & - & - & - & - & - & - & - & - & - & - & - \\
\hline $\begin{array}{l}\text { Bed } \\
\text { elevation }\end{array}$ & - & - & - & - & - & - & - & - & - & - & \\
\hline $\begin{array}{l}\text { Low chord } \\
\text { to bed }\end{array}$ & - & - & - & - & - & - & - & - & - & - & \\
\hline
\end{tabular}

Source (FEMA, VTAOT, Other)?

Comments: NO CROSS SECTION INFORMATION

\begin{tabular}{|l|l|l|l|l|l|l|l|l|l|l|l|}
\hline Station & - & - & - & - & - & - & - & - & - & - & - \\
\hline Feature & - & - & - & - & - & - & - & - & - & - & - \\
\hline $\begin{array}{l}\text { Low chord } \\
\text { elevation }\end{array}$ & - & - & - & - & - & - & - & - & - & - & - \\
\hline $\begin{array}{l}\text { Bed } \\
\text { elevation }\end{array}$ & - & - & - & - & - & - & - & - & - & - & - \\
\hline $\begin{array}{l}\text { Low chord } \\
\text { to bed }\end{array}$ & - & - & - & - & - & - & - & - & - & - & - \\
\hline Station & - & - & - & - & - & - & - & - & - & - & - \\
\hline Feature & - & - & - & - & - & - & - & - & - & - & - \\
\hline $\begin{array}{l}\text { Low chord } \\
\text { elevation }\end{array}$ & - & - & - & - & - & - & - & - & - & - & - \\
\hline $\begin{array}{l}\text { Bed } \\
\text { levation }\end{array}$ & - & - & - & - & - & - & - & - & - & - & - \\
\hline $\begin{array}{l}\text { Low chord } \\
\text { to bed }\end{array}$ & - & - & - & - & - & - & - & - & - & - & - \\
\hline
\end{tabular}




\section{APPENDIX E: \\ LEVEL I DATA FORM}


U. S. Geological Survey

Bridge Field Data Collection and Processing Form

Qa/Qc Check by: $\mathbf{C G}$ Date: $\mathbf{1 / 2 9 / 9 6}$

Computerized by: $\mathbf{C G}$ Date: $2 / 5 / 96$

\section{Structure Number MENDTH00070020}

Reviewd by: SAW Date: 10/17/97

\section{A. General Location Descriptive}

1. Data collected by (First Initial, Full last name) $\underline{\mathbf{T}}$. Severance

Date $(M M / D D / Y Y)$

09

$27 / 1995$

2. Highway District Number $\mathbf{0 3}$

County Rutland (021)

Mile marker -

Waterway (I - 6) Mendon Brook

Route Number TH 007

Town Mendon (44125)

Road Name -

Hydrologic Unit Code: $\mathbf{0 2 0 1 0 0 0 2}$

3. Descriptive comments:

This temporary steel bridge laid over old structure. The bridge is located 0.7 miles from the junction with US 4.

\section{B. Bridge Deck Observations}
4. Surface cover... LBUS 6
RBUS 6
LBDS 6
RBDS 6
Overall 6

(2b us,ds,lb,rb: 1- Urban; 2- Suburban; 3- Row crops; 4- Pasture; 5- Shrub- and brushland; 6- Forest; 7- Wetland)
5. Ambient water surface... US 2
UB 1
DS 2
(1- pool; 2- riffle)

6. Bridge structure type 1 (1- single span; 2- multiple span; 3- single arch; 4- multiple arch; 5- cylindrical culvert; 6- box culvert; or 7- other)
7. Bridge length $\mathbf{3 0}$
(feet)
Span length 26d
(feet)
Bridge width 14 (feet)

\section{Road approach to bridge:}
8. LB 2 RB 1
( 0 even, 1- lower, 2- higher)
9. LB_2
RB $\underline{2}$
(1- Paved, 2- Not paved)

10. Embankment slope (run / rise in feet / foot)

US left

US right

\begin{tabular}{|c|c|c|c|}
\hline \multicolumn{2}{|c|}{ Protection } & \multirow{2}{*}{ 13.Erosion } & 14.Severity \\
\cline { 6 - 6 } & 12.Cond. & & \\
\hline $\mathbf{0}$ & - & $\mathbf{0}$ & - \\
\hline
\end{tabular}

LBUS

RBUS

RBDS

LBDS

\begin{tabular}{l}
0 \\
0 \\
\hline 0
\end{tabular}

Bank protection types: 0 - none; 1- $<12$ inches;

2- $<36$ inches; 3- $<48$ inches

4- < 60 inches; 5- wall / artificial levee

Bank protection conditions: 1- good; 2- slumped;

3- eroded; 4- failed

Erosion: 0 - none; 1- channel erosion; 2 -

road wash; 3- both; 4- other

Erosion Severity: 0 - none; 1- slight; 2- moderate; 3- severe

\section{Channel approach to bridge (BF):}

15. Angle of approach: $\mathbf{5}$

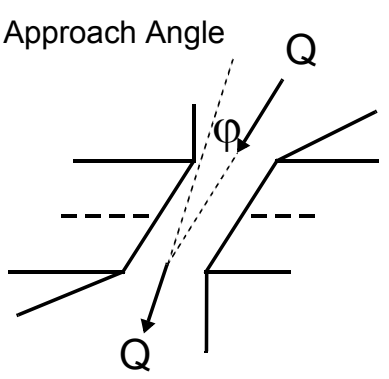

16. Bridge skew: $\mathbf{4 0}$ Bridge Skew Angle

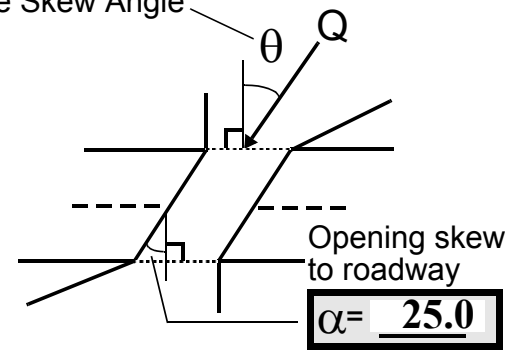

17. Channel impact zone 1: Exist? $\mathbf{Y}(Y$ or $N)$

Where? RB (LB, RB) Severity 2

Range? $\underline{50}$ feet $\underline{\text { US }}$ (US, UB, DS) to 16 feet $\underline{\mathbf{U B}}$

Channel impact zone 2: $\quad$ Exist? $\mathbf{N}(Y$ or $N)$

Where? - $(L B, R B) \quad$ Severity -

Range? - _ feet - $(U S, U B, D S)$ to -

Impact Severity: 0- none to very slight; 1- Slight; 2- Moderate; 3- Severe 
18. Bridge Type: 1a

1a- Vertical abutments with wingwalls

$1 \mathrm{~b}$ - Vertical abutments without wingwalls

2- Vertical abutments and wingwalls, sloping embankment

Wingwalls parallel to abut. face

3- Spill through abutments

4- Sloping embankment, vertical wingwalls and abutments

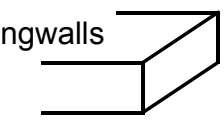

1a with wingwalls

Wingwall angle less than $90^{\circ}$.

19. Bridge Deck Comments (surface cover variations, measured bridge and span lengths, bridge type variations, approach overflow width, etc.)

As measured during the site visit, the bridge length equals 29.0 feet, span length is 27.0 feet, and bridge width

is $\mathbf{1 4 . 0}$ feet.

13. Temporary structure is sitting on top of old structure with piled up dirt/gravel embankments on either bank which adjust for added height of temporary bridge deck. Much of dirt/gravel extends out both upstream and downstream. No noted erosion or protection.

\section{Upstream Channel Assessment}

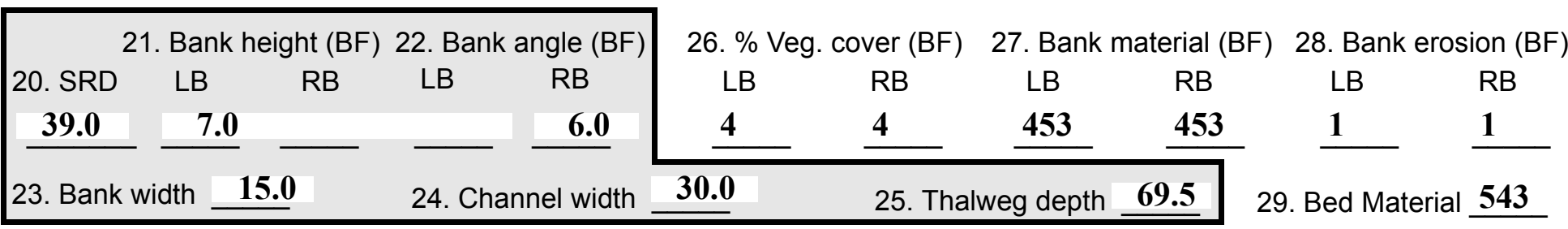

\section{0 .Bank protection type:}

LB $\underline{0}$

RB 0

31. Bank protection condition: LB -

$\mathrm{RB}$ -

SRD - Section ref. dist. to US face \% Vegetation (Veg) cover: 1- 0 to 25\%; 2- 26 to 50\%; 3- 51 to $75 \%$; 4- 76 to $100 \%$

Bed and bank Material: 0- organics; 1- silt / clay, < 1/16mm; 2- sand, 1/16 - 2mm; 3- gravel, 2 - 64mm;

4- cobble, 64 - 256mm; 5- boulder, > 256mm; 6- bedrock; 7- manmade

Bank Erosion: 0- not evident; 1- light fluvial; 2- moderate fluvial; 3- heavy fluvial / mass wasting

Bank protection types: 0- absent; 1- < 12 inches; 2- < 36 inches; 3- < 48 inches; 4- < 60 inches; 5- wall / artificial levee

Bank protection conditions: 1-good; 2- slumped; 3- eroded; 4- failed

32. Comments (bank material variation, minor inflows, protection extent, etc.):

27. Bank material is composed of cobble, boulder and gravel.

29. Bed material is composed of boulder, cobble and gravel.

The banks are naturally protected to some extent due to the presence of boulders and cobbles.

The left road approach is present along the upstream left bank and is fairly close to the channel at one point (within 10 feet).

There are large boulders on the upstream right bank, where one of the very large boulders is within one bridge length. 
36. Point bar extent: 126 feet $\underline{\text { US }}$ (US, UB) to $\underline{\mathbf{2 1 3}}$ feet $\underline{\text { US }}$ (US, UB, DS) positioned $\underline{\mathbf{0}} \%$ LB to $\underline{\mathbf{4 5}} \%$ RB

37. Material: 43

38. Point or side bar comments (Circle Point or Side; Note additional bars, material variation, status, etc.):

A second bar exists along the RB $250 \mathrm{ft}$ US to $320 \mathrm{ft} U S$; mid-bar distance $300 \mathrm{ft}$; mid-bar width $14 \mathrm{ft}$, posi-

tioned $30 \%$ LB to $100 \% \mathrm{RB}$; material is $4,3,5$. A cut bank is evident opposite this bar, but is not severe - large boulders present along bank provide some stabilization. The roadway travels along the left bank opposite second point bar. There is a third bar upstream of the second bar on the left bank.
39. Is a cut-bank present? $\mathbf{Y}$
( $Y$ or if $N$ type ctrl-n $c b)$
40. Where? RB
( $L B$ or $R B)$

41. Mid-bank distance: $\mathbf{5 5}$

43. Bank damage: 1

42. Cut bank extent: 45

feet $\underline{\text { SS }}$

(US, UB) to 85 feet $\underline{\mathbf{U S}}$ (US, UB, DS)

44. Cut bank comments (eg. additional cut banks, protection condition, etc.):

Many tree roots are exposed with sandy gravel sub-bank material.

A second cut bank exists $112 \mathrm{ft}$ US to $235 \mathrm{ft}$ US on RB.

A third cut bank exists at upper end of left bank point bar (188 ft US to $220 \mathrm{ft}$ US, mid-bank distance is $208 \mathrm{ft}$ ) Both banks have \#1 banks damage, with tree roots exposed. Trees are falling into the channel.

45. Is channel scour present? $\mathbf{N}$ (Y or if $N$ type ctrl-n cs) 46. Mid-scour distance: -

47. Scour dimensions: Length - _ Width _ _ Depth : _ _ _ Position _ _ \% \%B to -

48. Scour comments (eg. additional scour areas, local scouring process, etc.):

There is no channel scour, but there is natural localized scouring.
49. Are there major confluences? $\mathbf{Y}$
(Y or if $N$ type ctrl-n $m c)$
51. Confluence 1: Distance $\underline{\mathbf{4 0 0}}$
52. Enters on $\underline{\mathbf{L B}}$
( $L B$ or $R B)$
Confluence 2: Distance -
Enters on - (LB or $R B)$

54. Confluence comments (eg. confluence name):

Confluence name is Beaver Brook.

50. How many? 1

53. Type 1 (1- perennial; 2- ephemeral)
Type _ (1-perennial; 2- ephemeral)

\section{Under Bridge Channel Assessment}

55. Channel restraint (BF)? LB 2

\begin{tabular}{|ccccc}
\hline \multicolumn{2}{|c}{ 56. Height (BF) } & \multicolumn{3}{c}{57 Angle (BF) } \\
LB & RB & LB & RB \\
$\mathbf{3 0 . 0}$ & & & $\mathbf{1 . 0}$ & \\
\hline
\end{tabular}

58. Bank width (BF) -

59. Channel width -

61. Material (BF)

LB RB

$1 \quad 54$

Bed and bank Material: 0- organics; 1- silt / clay, < 1/16mm; 2- sand, 1/16 - 2mm; 3- gravel, 2 - 64mm; 4- cobble, 64 - 256mm; 5- boulder, > 256mm; 6- bedrock; 7- manmade

Bank Erosion: 0- not evident; 1- light fluvial; 2- moderate fluvial; 3- heavy fluvial / mass wasting

64. Comments (bank material variation, minor inflows, protection extent, etc.):

453

61. Bank material is composed of boulder and cobble.

63. Bed material is composed of cobble, boulder and gravel.

The water beneath the bridge is pooled.

There is a scour hole along the right bank at the upstream bridge face, extending approximately 5 feet upstream of bridge face. This hole is $8 \mathrm{ft}$ long, $3 \mathrm{ft}$ wide, $1.25 \mathrm{ft}$ deep, and positioned $65 \% \mathrm{LB}$ to $85 \% \mathrm{RB}$.

There is another scour hole along the left bank beneath the bridge. This hole is $5 \mathrm{ft}$ long, $2 \mathrm{ft}$ wide, $0.25 \mathrm{ft} \mathrm{deep}$, and positioned $20 \%$ LB to $25 \%$ RB. 
65. Debris and Ice Is there debris accumulation?

(Yor $N)$ 66. Where? $\underline{Y}$

(1- Upstream; 2- At bridge; 3- Both)

67. Debris Potential 1 (1- Low; 2- Moderate; 3- High)

68. Capture Efficiency 2

(1- Low; 2- Moderate; 3- High)

69. Is there evidence of ice build-up? 2 (Y or $N)$

Ice Blockage Potential $\underline{\mathbf{Y}}$

(1-Low; 2-Moderate; 3- High)

70. Debris and Ice Comments:

3

Logs are strewn along both banks upstream. Trees are falling into the channel.

\begin{tabular}{|l|c|c|c|c|c|c|c|c|}
\hline Abutments & $\begin{array}{c}\text { 71. Attack } \\
\angle \text { (BF) }\end{array}$ & $\begin{array}{c}\text { 72. Slope } \angle \\
\text { (Qmax) }\end{array}$ & $\begin{array}{c}\text { 73. Toe } \\
\text { loc. (BF) }\end{array}$ & $\begin{array}{c}\text { 74. Scour } \\
\text { Condition }\end{array}$ & $\begin{array}{c}75 . \text { Scour } \\
\text { depth }\end{array}$ & $\begin{array}{c}\text { 76. Exposure } \\
\text { depth }\end{array}$ & 77. Material & 78. Length \\
\hline LABUT & & - & $\mathbf{9 0}$ & $\mathbf{2}$ & $\mathbf{1 ~ ( 3 )}$ & $\mathbf{0}$ & - & $\mathbf{9 0 . 0}$ \\
\hline RABUT & $\mathbf{1}$ & $\mathbf{2 5}$ & $\mathbf{9 0}$ & & & $\mathbf{2}$ & $\mathbf{1}(\mathbf{3})$ & $\mathbf{2 1 . 5}$ \\
\hline
\end{tabular}

Pushed: $L B$ or RB

Toe Location (Loc.): 0- even, 1- set back, 2- protrudes

Scour cond.: 0- not evident; 1- evident (comment); 2- footing exposed; 3-undermined footing; 4- piling exposed; 5- settled; 6- failed

Materials: 1- Concrete; 2- Stone masonry or drywall; 3- steel or metal; 4- wood

79. Abutment comments (eg. undermined penetration, unusual scour processes, debris, etc.):

0

1

74. Abutments are both undermined. The entire right abutment is exposed/undermined; at the upstream end there is $\mathbf{2 . 2 5} \mathrm{ft}$ of horizontal penetration underneath the wall.

75. Depth of water is not greater than upstream/downstream thalweg depth of $1 \mathrm{ft}$, therefore there is no measurable scour.

76. There are no footings. The right abutment is undermined $1 \mathrm{ft}$ at upstream end. The left abutment is undermined $0.5 \mathrm{ft}$ at upstream end. A bar exists on the left at the downstream end.

80. Wingwalls:

$\begin{array}{llll}\text { Exist? Material? } & \text { Scour } & \text { Scour Exposure } & \text { Angle? Length? } \\ \text { Condition? depth? } & \text { depth? }\end{array}$

USLWW:

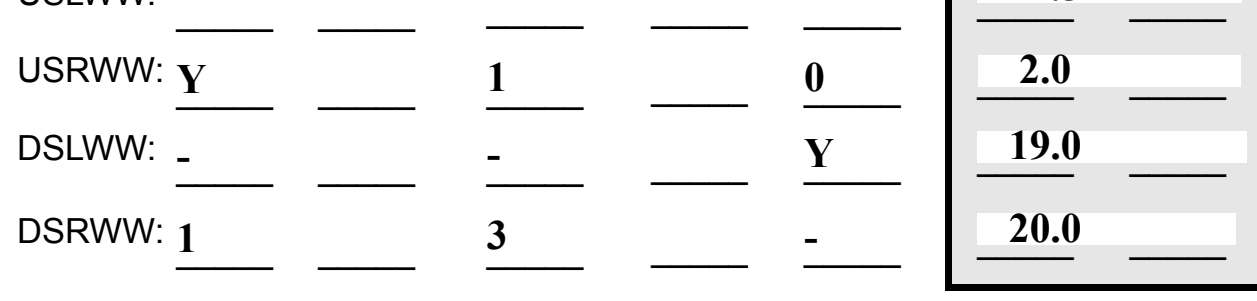

Wingwall materials: 1- Concrete; 2- Stone masonry or drywall; 3- steel or metal; 4- wood

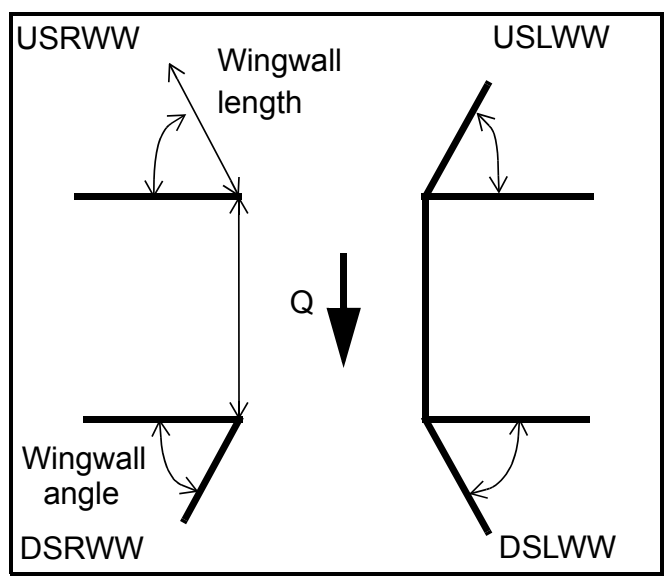

82. Bank / Bridge Protection:

\begin{tabular}{|l|l|l|l|l|l|l|l|l|}
\hline Location & USLWW & USRWW & LABUT & RABUT & LB & RB & DSLWW & DSRWW \\
\hline Type & - & - & $\mathbf{Y}$ & - & $\mathbf{1}$ & - & - & - \\
\hline Condition & $\mathbf{N}$ & - & $\mathbf{1}$ & - & $\mathbf{2}$ & - & - & - \\
\hline Extent & - & - & $\mathbf{3}$ & $\mathbf{2}$ & $\mathbf{0}$ & $\mathbf{0}$ & $\mathbf{0}$ & - \\
\hline
\end{tabular}

Bank / Bridge protection types: 0- absent; 1- < 12 inches; 2- < 36 inches; 3- < 48 inches; 4- < 60 inches; 
83. Wingwall and protection comments (eg. undermined penetration, unusual scour processes, etc.):

-
-
-
-
-
-
-
-
0
-
-

\section{Piers:}

84. Are there piers? 80. (Y or if $N$ type ctrl-n pr)

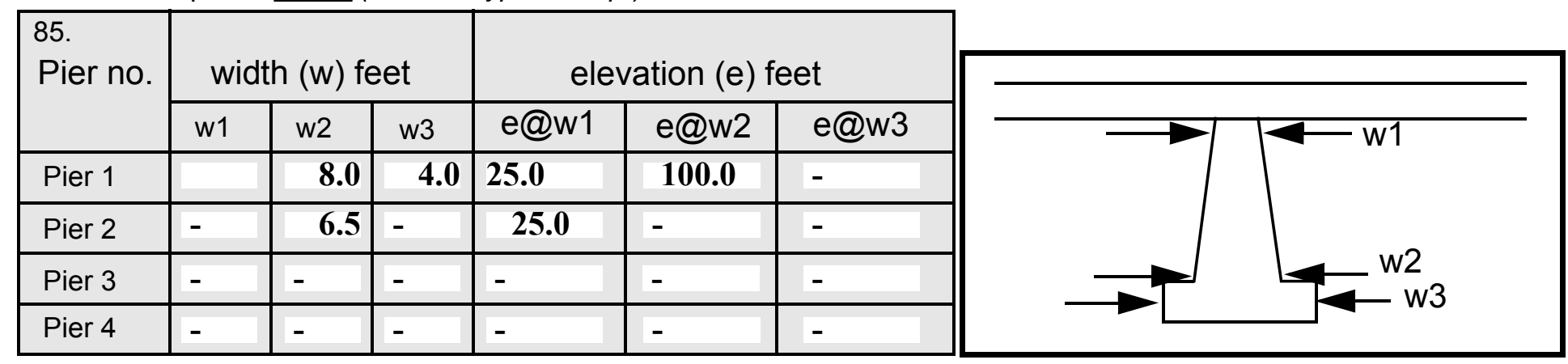

\begin{tabular}{|l|l|l|l|l|}
\hline Level 1 Pier Descr. & \multicolumn{1}{|c|}{1} & \multicolumn{1}{|c|}{2} & \multicolumn{1}{|c|}{3} & \multicolumn{1}{|c|}{ 86. Location (BF) } \\
\hline 87. Type & At the & foot- & ture/ & ed). \\
\hline 88. Material & DSR & ing & mate & The \\
\hline 89. Shape & WW & (or it & rial & DSR \\
\hline 90. Inclined? & there & coul & that & WW \\
\hline 91. Attack $\angle$ (BF) & appe & d & esca & was \\
\hline 92. Pushed & to be & ply & the & ed \\
\hline 93. Length (feet) & - & - & - & - \\
\hline 94. \# of piles & rema & be & form & over \\
\hline 95. Cross-members & ins & the & whil & a \\
\hline 96. Scour Condition & of a & con- & e it & boul- \\
\hline 97. Scour depth & con- & crete & was & der. \\
\hline 98. Exposure depth & crete & mix- & pour & Whil \\
\hline
\end{tabular}

LFP, LTB, LB, MCL, MCM, MCR, RB, RTB, RFP

1- Solid pier, 2- column, 3- bent

1-Wood; 2- concrete; 3- metal; 4- stone

1- Round; 2- Square; 3- Pointed

Y-yes; $N$ - no

$L B$ or $R B$

0- none; 1- laterals; 2- diagonals; 3- both

0- not evident; 1- evident (comment);

2- footing exposed; 3- piling exposed;

4- undermined footing; 5- settled; 6- failed 
99. Pier comments (eg. undermined penetration, protection and protection extent, unusual scour processes, etc.):

e the DSRWW is undermined, no scour depth was noted as the flow depth is less than the average thalweg depth of $1.0 \mathrm{ft}$. There is no DSLWW.

The USRWW is undermined 0.75 feet vertically and the undermining penetrates 2.0 feet horizontally underneath the wall. No footing is evident. Note that the water depth is less than the upstream/downstream thalweg depth of 1.0 feet so no scour depth was noted.

$\mathbf{N}$

100.

\section{E. Downstream Channel Assessment}

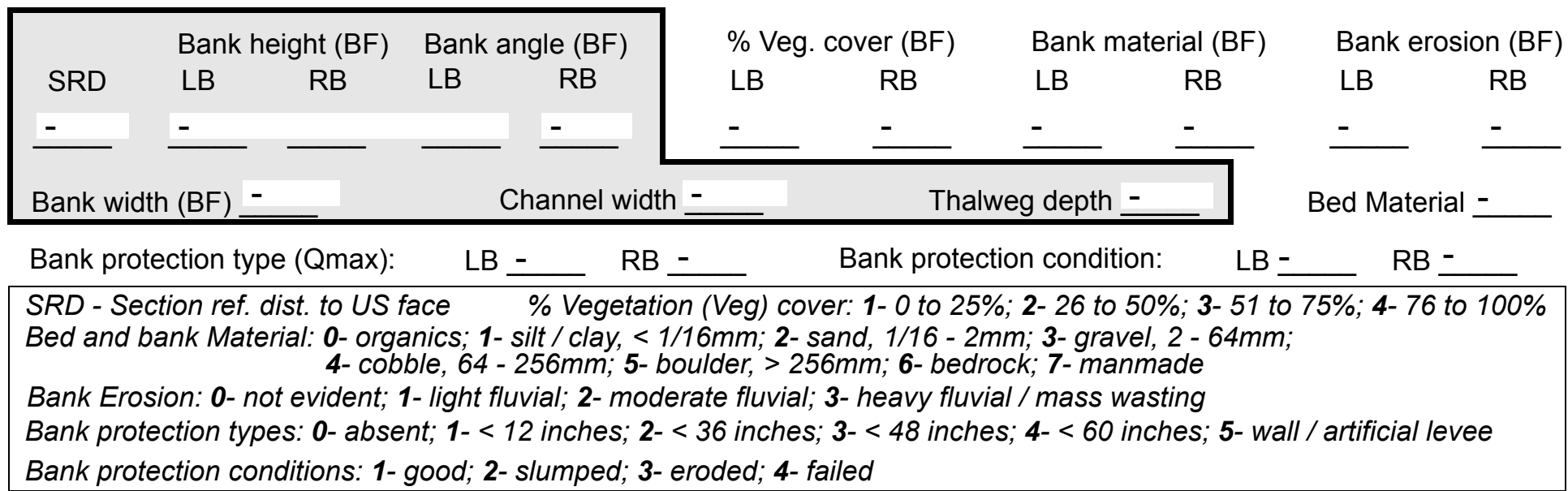

Comments (eg. bank material variation, minor inflows, protection extent, etc.):

$-$

$-$

$-$

$-$

$-$

$-$

$-$

-

$-$

$-$

101. Is a drop structure present? _ ( $Y$ or $N$, if $N$ type ctrl-n ds) 102. Distance: ___ feet
103. Drop: - feet
104. Structure material:
(1- steel sheet pile; 2- wood pile; 3- concrete; 4- other)

105. Drop structure comments (eg. downstream scour depth): 
106. Point/Side bar present? (Y or $N$. if $N$ type ctrl-n pb)Mid-bar distance:

Mid-bar width: -

Point bar extent: feet -

(US, UB, DS) to feet (US, UB, DS) positioned $\%$ LB to $\% \mathrm{RB}$ Material:

Point or side bar comments (Circle Point or Side; note additional bars, material variation, status, etc.):

S a cut-bank present? $\mathbf{N}$ (Y or if $N$ type ctrl-n cb) Where? $\underline{\mathbf{O}}$ (LB or RB) Mid-bank distance: PIE Cut bank extent: $\underline{\mathbf{R S}}$ feet ___ (US, UB, DS) to feet (US, UB, DS)

Bank damage: (1- eroded and/or creep; 2- slip failure; 3- block failure)

Cut bank comments (eg. additional cut banks, protection condition, etc.):

Is channel scour present? Scour dimensions: Length $\underline{4}$ Width 54 ( $Y$ or if $N$ type ctrl-n cs)

Mid-scour distance: $\underline{4}$

Scour comments (eg. additional scour areas, local scouring process, etc.): 453

0

0

Are there major confluences? Confluence 1: Distance Pro-

Confluence 2: Distance was Enters on tec- $(L B$ or RB)

Enters on not (LB or RB)

Positioned $\underline{1} \%$ LB to $\underline{1} \%$ RB

Confluence comments (eg. confluence name):

ed along the banks. Bank material consists of boulders and cobble. The boulder/cobble material act as natural protection.

\section{F. Geomorphic Channel Assessment}

107. Stage of reach evolution Be
1- Constructed

2- Stable

3- Aggraded

4- Degraded

5- Laterally unstable

6- Vertically and laterally unstable 
108. Evolution comments (Channel evolution not considering bridge effects; See HEC-20, Figure 1 for geomorphic descriptors):

d material consists of cobble, boulders, and gravel. 


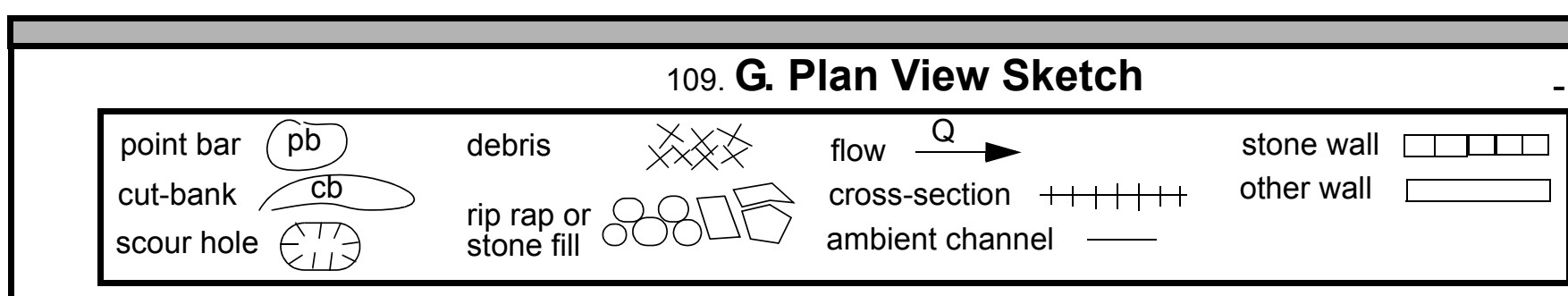


APPENDIX F:

SCOUR COMPUTATIONS 


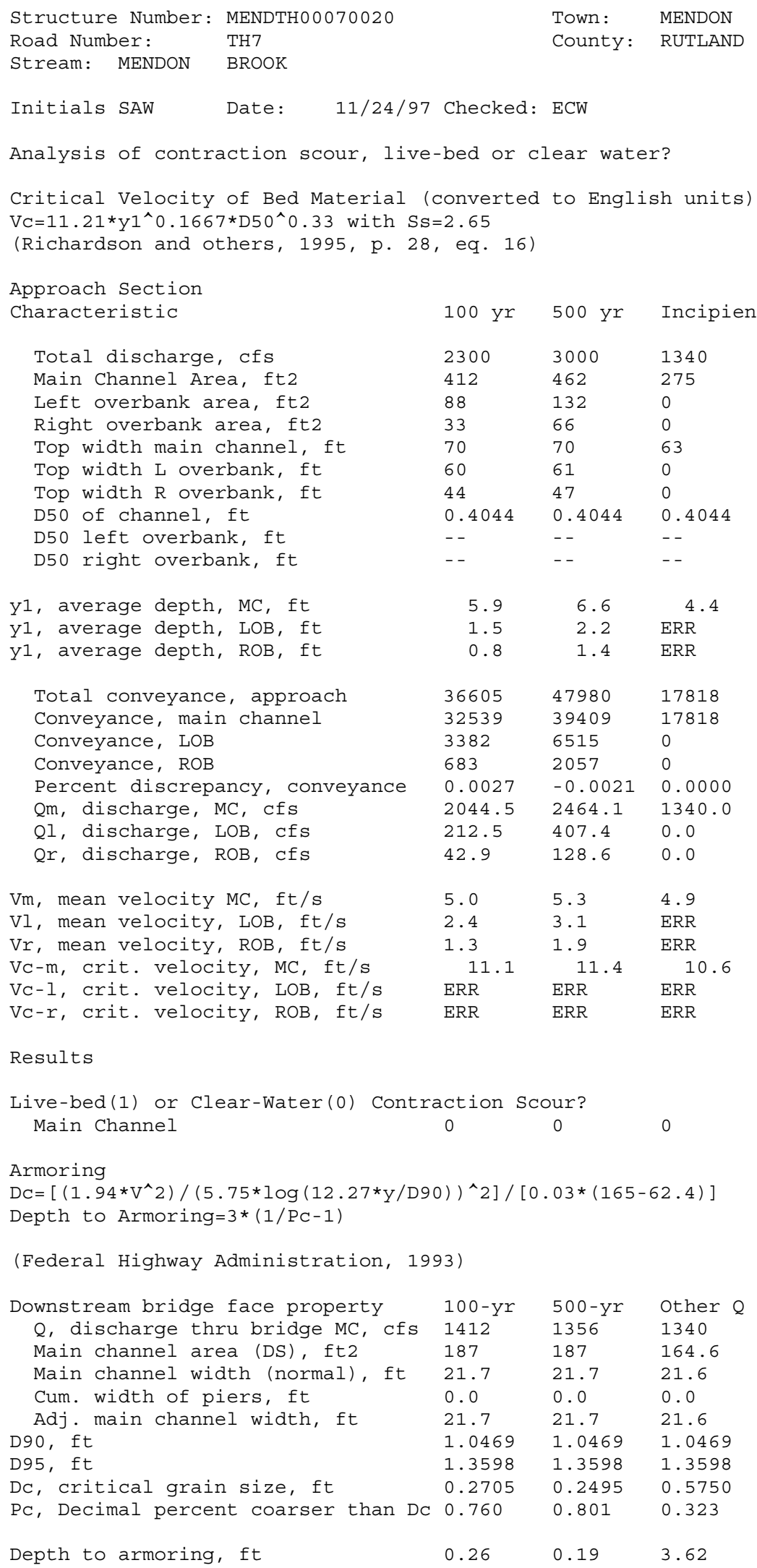


Clear water Contraction Scour in MAIN CHANNEL

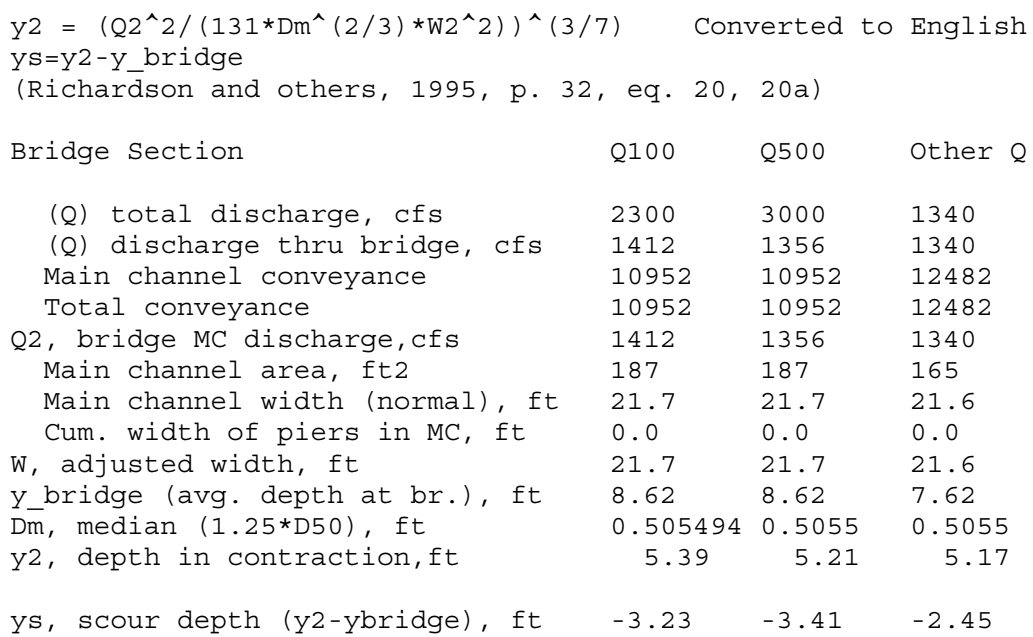

Pressure Flow Scour (contraction scour for orifice flow conditions)

\begin{tabular}{|c|c|c|c|}
\hline $\begin{array}{l}\text { Chang pressure flow equation } \\
\mathrm{Cq}=1 / \mathrm{Cf} * \mathrm{CC} \quad \mathrm{Cf}=1.5 * \mathrm{Fr}^{\wedge} 0.43 \quad(<=1)\end{array}$ & $\begin{array}{l}\mathrm{Hb}+\mathrm{Ys}=\mathrm{C} \\
\mathrm{CC}=\mathrm{SQRT}\end{array}$ & $\begin{array}{l}\text { * qbr / Vc } \\
0.10(\mathrm{Hb}\end{array}$ & \\
\hline $\begin{array}{l}\text { Umbrell pressure flow equation } \\
(\mathrm{Hb}+\mathrm{Ys}) / \mathrm{ya}=1.1021 *[(1-\mathrm{w} / \mathrm{ya}) *(\mathrm{Va} / \mathrm{VC}) \\
\text { (Richardson and other, 1995, p. } 144\end{array}$ & & & \\
\hline & Q100 & Q500 & Othes \\
\hline 2, total, cfs & 2300 & 3000 & 1340 \\
\hline , thru bridge $M C$, cfs & 1412 & 1356 & \\
\hline Tc, critical velocity, ft/s & 11.14 & 11.35 & 0.60 \\
\hline Ta, velocity MC approach, ft/s & 4.96 & 5.33 & \\
\hline Iain channel width (normal), ft & 21.7 & 21.7 & .6 \\
\hline um. width of piers in MC, ft & 0.0 & 0.0 & 0 \\
\hline I, adjusted width, ft & 21.7 & 21.7 & 21.6 \\
\hline br, unit discharge, ft2/s & 65.1 & 62.5 & 62.0 \\
\hline rea of full opening, ft2 & 187.0 & 187.0 & 164.6 \\
\hline b, depth of full opening, ft & 8.62 & 8.62 & 7.62 \\
\hline$r$, froude number, bridge $\mathrm{MC}$ & 0.48 & 0.46 & 0 \\
\hline Cf, Fr correction factor $(<=1.0)$ & 1.00 & 1.00 & 0.00 \\
\hline **Area at downstream face, ft 2 & $\mathrm{~N} / \mathrm{A}$ & $\mathrm{N} / \mathrm{A}$ & $\mathrm{N} / \mathrm{A}$ \\
\hline **Hb, depth at downstream face, ft & $\mathrm{N} / \mathrm{A}$ & $\mathrm{N} / \mathrm{A}$ & $\mathrm{N} / \mathrm{A}$ \\
\hline **Fr, Froude number at DS face & ERR & ERR & ERR \\
\hline$* * \mathrm{Cf}$, for downstream face $(<=1.0)$ & $\mathrm{N} / \mathrm{A}$ & $\mathrm{N} / \mathrm{A}$ & $\mathrm{N} / \mathrm{A}$ \\
\hline Elevation of Low steel, ft & 502.26 & 502.26 & 0 \\
\hline Elevation of Bed, ft & 493.64 & 493.64 & -7.62 \\
\hline levation of Approach, ft & 504.31 & 505.03 & 0 \\
\hline Friction loss, approach, ft & 0.17 & 0.2 & 0 \\
\hline Elevation of WS immediately US, ft & 504.14 & 504.83 & 0.00 \\
\hline ya, depth immediately US, ft & 10.50 & 11.19 & 7.62 \\
\hline Mean elevation of deck, ft & 505.85 & 505.85 & 505.8 \\
\hline w, depth of overflow, ft $(>=0)$ & 0.00 & 0.00 & 0.00 \\
\hline Cc, vert contrac correction $(<=1.0)$ & 0.95 & 0.94 & 1.00 \\
\hline$* * C c$, for downstream face $(<=1.0)$ & $\mathrm{ERR}$ & ERR & $\mathrm{ERR}$ \\
\hline s, scour w/Chang equation, ft & -2.48 & -2.73 & N/ \\
\hline s, scour w/Umbrell equation, ft & -1.51 & -0.80 & $\mathrm{~N} / \mathrm{A}$ \\
\hline
\end{tabular}

**=for UNsubmerged orifice flow using estimated downstream bridge face properties.

**Ys, scour w/Chang equation, ft $\mathrm{N} / \mathrm{A} \quad \mathrm{N} / \mathrm{A} \quad \mathrm{N} / \mathrm{A}$

**Ys, scour w/Umbrell equation, ft N/A N/A ERR

In UNsubmerged orifice flow, an adjusted scour depth using the Laursen equation results and the estimated downstream bridge face properties can also be computed (ys=y2-ybridgeDs)

$\begin{array}{llll}\text { Y2, from Laursen's equation, ft } & 5.39 & 5.21 & 5.17 \\ \text { WSEL at downstream face, ft } & -- & -- & -- \\ \text { Depth at downstream face, ft } & \text { N/A } & \text { N/A } & \text { N/A } \\ \text { depth of scour (Laursen), ft } & \text { N/A } & \text { N/A } & \text { N/A }\end{array}$

Ys, depth of scour (Laursen), ft N/A N/A N/A 


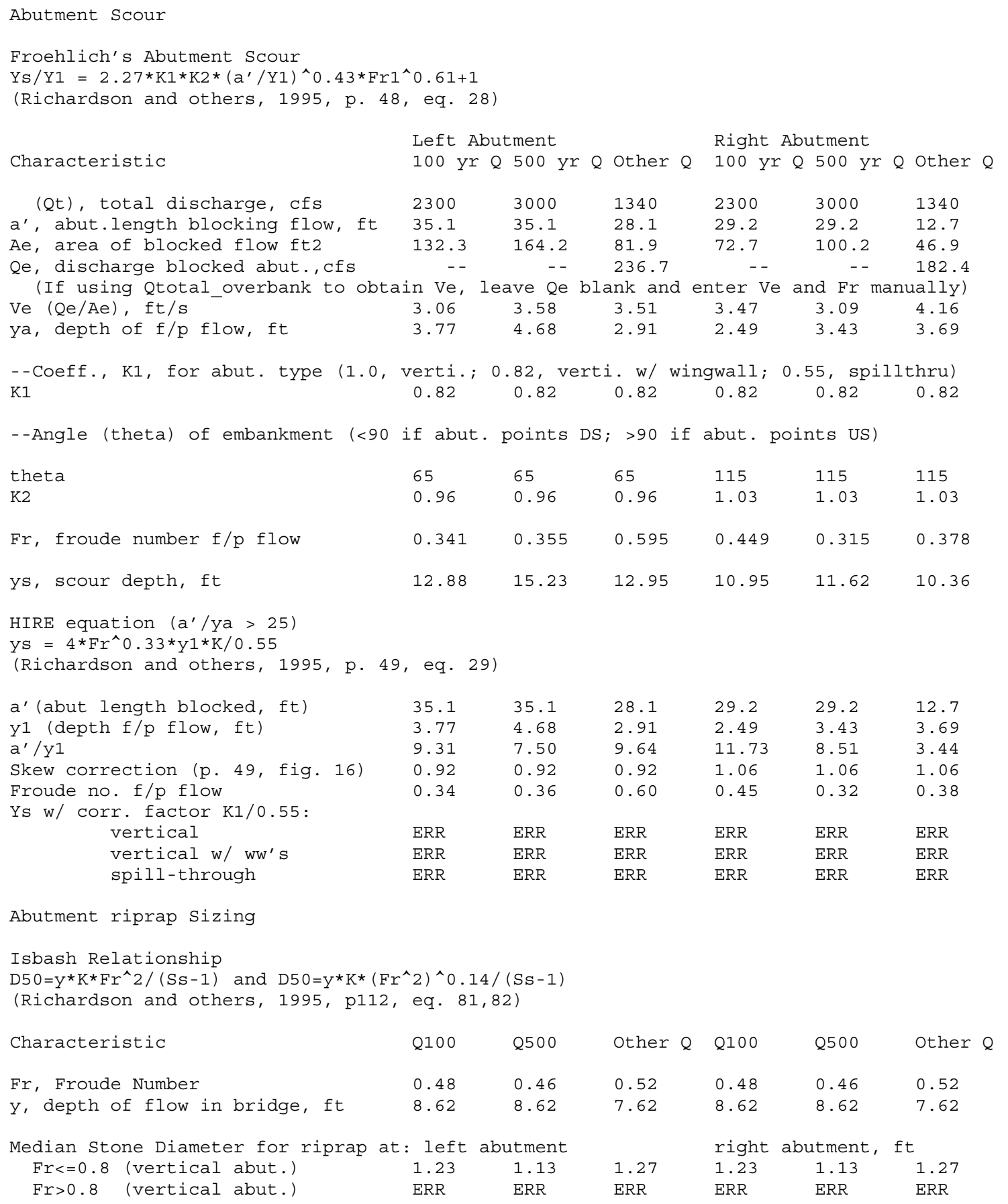

